\title{
Parentesco, Escravidão e Liberdade (Porto Feliz, São Paulo, século XIX)*
}

\author{
Kinship, Slavery and Freedom

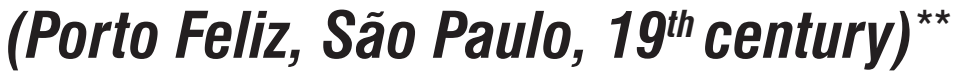

\author{
ROBERTO GUEDES \\ Professor Adjunto do Departamento de História e Economia \\ Universidade Federal Rural do Rio de Janeiro \\ Av. Governador Roberto Silveira, s/n, Moquetá, Nova Iguaçu-RJ, CEP 26210-210 \\ robguedes@superig.com.br
}

RESUMO Focado na cidade de Porto Feliz, capitania/província de São Paulo, o trabalho analisa como motivos de ordem familiar influenciaram conflitos entre senhores e escravos em torno da liberdade e da escravidão. Nas últimas décadas da escravidão, em meio a pressões em prol da liberdade e de relativa perda de legitimidade da escravidão, nota-se, por parte de uma família senhorial, o esforço em preservar essa condição construída ao longo de gerações. Senhores com (ante)passado escravo e famílias cativas que almejavam a liberdade conduziram-se por motivos parentais, ainda que com objetivos diferentes.

\footnotetext{
* Artigo recebido em: 04/11/2009. Aprovado em: 06/07/2010.

** Esta pesquisa é financiada pela Fundação de Amparo à Pesquisa do Estado do Rio de Janeiro (FAPERJ). Agradeço os valiosos comentários de Beatriz Mamigonian, Keila Grinberg e Regina Xavier, quando do IV Encontro de Escravidão e Liberdade no Brasil Meridional (2009). Mas os erros são de minha responsabilidade.
} 
Palavras-chave escravidão, parentesco, mobilidade social

ABSTRACT Focused in Porto Feliz, captaincy/province of São Paulo, this study analyzes how family reasons influenced conflicts between masters and slaves about freedom and slavery. At the ends of slavery, with pressures for freedom and relative loss of legitimacy of slavery, a master family tried to preserve its social position, built up over generations and over slavery. By other hand, slaves families sought to achieve freedom. Thus, a former slave family and a slave family joined forces to defend their kinships interests.

Keywords slavery, kinship, social mobility

Faltavam 11 dias para o Natal de 1864, mas a expectativa da festa religiosa não impediu Rosa Maria de Arruda de mover uma ação de manutenção de liberdade a favor de seu afilhado, o crioulo José. Na petição ao juiz municipal, ela disse que seu afilhado, filho de Generosa da Rocha, fora batizado "como livre", mas estava em poder de João Leite de Camargo, que o conservava em cativeiro. Na "qualidade de madrinha", Rosa enfatizou que devia "zelar sobre a sorte de seu afilhado" e nessa condição requereu depositário e curador para promover a ação de manutenção de liberdade. Insistiu que era continente que seu afilhado começasse a gozar de liberdade, "visto ter sido batizado como livre", o que provava com a certidão de batismo. Porém, o réu João Leite de Camargo juntou aos autos uma petição, na qual argumentava que continuava formalmente desfrutando dos serviços do "preto de nome José, filho da escrava Generosa, doada pelo Reverendo André da Rocha Abreu à Esmelinda", sua mulher. Na doação, a escrava Generosa e "sua produção" só seriam livres depois da morte de Esmelinda. No entanto, continuava o réu, Rosa o denunciou ao juízo, alegando que ele "desfrutava ilegalmente os serviços do preto mencionado, considerando-o como escravo". Dizendo-se "protetora" de seu afilhado obteve deferimento do juízo para depósito e curador, mas Camargo juntou ao auto a escritura da doação da escrava Generosa com suas condições de liberdade, a fim de provar o direito que teria sobre José. Por "consequência desse direito", achava-se "esbulhado", sofrendo em "seus interesses, e o pior de tudo a injúria resultante da falsidade da denúncia". 1

Nos dizeres de Rosa foi o dever de madrinha o que a levou a zelar por seu afilhado, não tanto a escravidão ou a liberdade. Antes, era a obrigação do parentesco religioso. Para isso, justificava suas intenções pelo

1 Museu Republicano Convenção de Itu (MRCI). Pasta 12, doc 1. Ação de Manutenção de Liberdade. 
solene ato do batismo. Ser batizado como livre era o bastante, ou deveria ser, para que se gozasse da condição de livre. Suas próprias reclamações demonstram que não era bem assim, ao menos não em todos os casos, mas, ao recorrer ao registro de batismo e a uma declaração de um padre para comprovar a liberdade, não o fez de forma aleatória. As Constituições Primeiras do Arcebispado da Bahia, de 1720, postulavam que declarações de padres teriam força de escritura. ${ }^{2}$

Por seu lado, o réu João de Camargo perdia em seus interesses e, "o pior de tudo", queixava-se da "injúria resultante da falsidade da denúncia": a vexação pública. A doação a qual se referiu fora feita pelo padre André da Rocha Abreu à sua esposa, então denominada "mulatinha Esmelinda", em 1820, quando a forra Esmelinda Maria da Rocha recebeu dois escravos. Tudo registrado pelo tabelião de notas. Assim, em 1864, à revelia do ato religioso e do registro batismal que o padre André tantas vezes realizou, João de Camargo sublinhava uma doação lavrada em cartório, um documento legalizado fora do âmbito da Igreja Católica. ${ }^{3}$

Mais ainda, o que sobressai nos argumentos dos litigantes é que, para além da escravidão e da liberdade, mas permeando-as, parentesco e honra estavam em causa, tudo a se misturar no auto. Mas o que o auto de ação de manutenção de liberdade não demonstra é a intricada rede de relações de parentesco entre as partes. Tudo indica que os ressentimentos derivam do tempo em que eram quase todos escravos e forros agregados do padre André da Rocha Abreu, falecido em 1820. A partir de então, certos cativos permaneceram sob o domínio do forro senhor Jesuíno José da Rocha, falecido em 1836. Estes anos remontam, respectivamente, a 44 e 28 anos antes do processo.

Quatorze anos depois da petição de Rosa, em 1878, a escrava Firmina e seus filhos menores, por meio de um curador, também moveram uma ação de manutenção de liberdade contra outro membro da família Rocha, Jesuíno José da Rocha Filho. ${ }^{4}$ A escrava Firmina era "concubina" de José Rodrigues Viana, que fora criado pela mãe do mesmo Jesuíno Filho, falecida no mesmo ano de 1878. Uma das testemunhas pró cativa disse que ouvira de José Rodrigues Viana que Jesuíno Filho, "expelindo-o da sua morada, tomará posse de sua concubina e filhos". ${ }^{5}$ Até então, Firmina e seus filhos conviveram em um cativeiro pelo menos suportável sob o poder de dona Feliciana. O caso se relaciona, com efeito, à difícil questão, quando da

2 VIDE, Sebastião Monteiro da. Constituições Primeiras do Arcebispado da Bahia. Coimbra: Real Colégio das Artes e da Companhia de Jesus, 1720. Título X do Livro V.

3 Sobre o confronto de esferas jurídicas leiga e religiosa no Brasil Imperial, cf. OLIVEIRA, Anderson J. Os bispos e os leigos. Reforma Católica e Irmandades no Rio de Janeiro Imperial. Revista Locus, Juiz de Fora, n.2, v.8, p.71-81, 2002.

4 Filho não compõe seu nome, mas manterei no texto para diferenciá-lo do pai.

$5 \mathrm{MRCl}$. Pasta 12, doc 18. Ação de Manutenção de Liberdade. 
morte de um senhor, da transmissão de seu poder aos seus herdeiros, mas novamente o parentesco permeia a liberdade e a escravidão.

Pelo exposto, objetivamos contribuir para a compreensão das motivações familiares de autores e réus e de como os sentimentos de parentesco influenciaram a luta pela liberdade e pela manutenção da escravidão. ${ }^{6}$ Nessa perspectiva, por meio da análise de trajetórias familiares, observamos que ramos de famílias de ex-escravos que atingiram a condição senhorial pelejaram para assim se preservar até onde foi possível. Por outro lado, famílias de escravos há muito tempo escravizada tentaram dar um basta. Para as duas partes, razões familiares e parentais eram o pano de fundo. Para testar essas hipóteses, usamos listas nominativas, testamentos, inventários post-mortem, ações de liberdade, etc., cruzando fontes e circunscrevendo o objeto. ${ }^{7}$

\section{Porto Feliz, século XIX}

Abordar as contendas familiares em torno da escravidão e da liberdade remete à viabilidade demográfica da escravidão no Oitocentos. Até meados da centúria, impulsionada pelo tráfico atlântico de cativos, a população escrava cresceu intensamente em Porto Feliz. Em 1803, eram 1.913, ou 32\% da população total, passando para 4.982 em 1829, quase 52\%. Reduzem-se a 4.122 (46\%) em 1843; redução esta que se relaciona mais ao desmembramento de freguesias que se tornaram vilas do que ao refluxo do tráfico. Mas a partir de meados do século, a diminuição da população escrava se fez a passos largos. De $46 \%$ do total em 1843, os cativos se reduziram a 1.567 (35\%) em 1854, 1.547 (20,2\%) em 1874 e 594 (10\%) em 1886. ${ }^{8}$

Nesse cenário, como foi possível a manutenção da condição senhorial dos membros da família Rocha? Deviam saber da difícil reprodução da escravaria em Porto Feliz dos anos 1860, 1870 e 1880, época das ações processuais movidas em prol dos cativos. Aos senhores só restava resistir para preservar os escravos sob seu poder. José, batizado em 1841, protegido se sua madrinha, devia ter 23 anos de idade em 1864. A escrava Firmina

6 Sobre ações de liberdade, vide GRINBERG, Keila. Liberata - a lei da ambiguidade: as ações de liberdade da Corte de Apelação do Rio de Janeiro no século XIX. $2^{\mathrm{a}}$.ed. Rio de Janeiro: Relume Dumará, 1994. Recentemente, da mesma autora, sobre o aspecto familiar, GRINBERG, Keila. Senhores sem escravos: a propósito das ações de escravidão no Brasil Imperial. Revista Almanack Braziliense, São Paulo, v.6, p.1-11, 2007. Também, CAMPOS, Adriana Pereira. Escravidão e liberdade nos tribunais. Revista Histórica, São Paulo, n.9, s/p, 2006.

7 LEVI, Giovanni. A herança imaterial. Trajetória de um exorcista no Piemonte do século XVII. Rio de Janeiro: Civilização Brasileira, 2000; GINZBURG, Carlo. A micro-história e outros ensaios. Lisboa: Difel, 1991; DÍAZ, Aisnara Perera e FUENTES, María de los A. Meriño. Esclavitud, familia y parroquia en Cuba: otra mirada desde la microhistoria. Santiago de Cuba: Editorial Oriente, 2006.

8 Tratamos da reprodução da escravaria em Porto Feliz em GUEDES, Roberto. Estrutura de posse e Demografia escrava em Porto Feliz (São Paulo, 1798-1843). In: PAIVA, Eduardo França e IVO, Isnara Pereira. (eds.) Escravidão, mestiçagem e histórias comparadas. São Paulo: Annablume, 2008. Para o período entre 1854 e 1890, cf. POLAZ, Karen T. M. Porto Feliz: evolução demográfica, imigração e propriedade da terra nos séculos XIX e XX. Anais da Associação Brasileira de História Econômica, p.1-4, 2006. 
tinha dois filhos menores em 1878. Eram todos mão-de-obra escrava efetiva e potencial, a única via de reprodução da escravidão e da condição senhorial para a família Rocha. As ações de liberdade colocavam em xeque, não apenas a condição senhorial, mas o longo status senhorial da família Rocha.

Status senhorial de uma sociedade escravista, bem entendido, posto que tal sociedade se caracteriza, não só pela presença da mão-de-obra escrava, mas "principalmente devido às distinções jurídicas entre escravos e livres, aos princípios hierárquicos baseados na escravidão e na raça, às atitudes senhoriais dos proprietários e à deferência dos socialmente inferiores". ${ }^{9}$ Considerando esse traço e o momento das ações processuais em favor da liberdade, a pergunta a ser feita é se, de fato, os Rochas deixaram de ser escravistas, ou seja, à redução demográfica da escravidão corresponderiam o definhamento das distinções jurídicas, dos princípios hierárquicos na escravidão, das atitudes senhoriais dos proprietários e da deferência dos socialmente inferiores?

Estudiosos da escravidão já se reportaram a estas questões. Há quem ateste que a perda da legitimidade da escravidão na segunda metade do Oitocentos se associou à concentração da propriedade escrava, pois o fim do tráfico atlântico de cativos, em 1850, impossibilitou o acesso à mão-deobra escrava para amplos segmentos sociais, o que levou ao descomprometimento para com a escravidão. ${ }^{10}$ Outros autores dão ênfase às pressões sociais dos cativos, que intensificaram ataques contra seus senhores nas décadas de 1870 e 1880. ${ }^{11}$ Outros, além desse último aspecto, sublinham a interferência do Estado e da legislação nas esferas pessoais de dominação, ou as lutas dos movimentos abolicionistas. ${ }^{12}$ Longe se está aqui de diminuir a contribuição de tais obras, mas acreditamos que os enormes esforços para acabar com a escravidão sugerem mesmo sua vitalidade. ${ }^{13} \mathrm{Na}$ segunda metade da centúria, a escravidão resistiu às pressões inglesas, ao fim do

9 SCHWARTZ, Stuart B. Segredos internos: engenhos e escravos na sociedade colonial, 1550-1835. São Paulo: Companhia das Letras, 1988, p. 209. Os socialmente inferiores são os escravos, e a palavra raça não é empregada com conotação biologizante.

10 CASTRO, Hebe Maria Mattos de. Das cores do silêncio: os significados da liberdade no sudeste escravista. Rio de Janeiro: Arquivo Nacional, 1995.

11 MACHADO, Maria H. P. Toledo. O plano e o pânico: movimentos sociais na década da abolição. Rio de Janeiro/ São Paulo: Editoria da UFRJ/Editora da Universidade de São Paulo, 1994; AZEVEDO, Celia Maria Marinho de. Onda negra, medo branco: o negro no imaginário das elites, século XIX. São Paulo: Annablume, 2004.

12 CHALHOUB, Sidney. Visões da liberdade. uma história das últimas décadas da escravidão na Corte. São Paulo: Companhia das Letras, 1990; MENDONÇA, Joseli Maria Nunes. Entre a mão e os anéis: a lei dos sexagenários e os caminhos da abolição no Brasil. Campinas: Editora UNICAMP, 1999; AZEVEDO, Célia Maria M. Abolicionismo: Estados Unidos e Brasil, uma história comparada (século XIX). São Paulo: Annablume, 2003. AZEVEDO, Elcine. Orfeu da Carapina. Campinas: Editora da UNICAMP, 1999.

13 Destacando a descontinuidade do que se convencionou chamar de processo abolicionista, abordei o tema da força da escravidão na segunda metade do século XIX para além da esfera familiar. GUEDES, Roberto. A Resistência da Escravidão (Porto Feliz, São Paulo, Século XIX). In: Anais do IV Encontro Escravidão e Liberdade no Brasil Meridional. Curitiba: UFPR, p.1-13, 2009. 
tráfico atlântico, à concentração da propriedade escrava, às investidas do Estado imperial, às pressões escravas e aos historidores abolicionistas. ${ }^{14}$

No plano das relações entre senhores e escravos, autores salientam também a perda da força moral da escravidão, quando o que era da alçada senhorial, como, por exemplo, escravizar e libertar, tornou-se objeto de contestação, sobretudo a alforria, ${ }^{15}$ pois solaparam-se aos poucos as atitudes senhoriais dos proprietários e a deferência dos socialmente inferiores. Evidente que Porto Feliz vivenciou tais mudanças, mas nada dos ataques à escravidão, acima referidos, foi um processo linear e evolutivo. ${ }^{16} \mathrm{~A}$ força da escravidão se observa entre senhores cujas famílias vivenciaram a escravidão, sem que isto Ihes fosse exclusivo. Como notou Grinberg, autores de ações de re-escravização muito frequentemente tinham ascendência escrava ou eram forros, mas senhores de poucos escravos. ${ }^{17}$ No entanto, os Rochas, ainda que tivessem poucos escravos, guardavam uma vivência de família senhorial. Seus valores eram escravistas. Para entender a vitalidade desses valores entre os forros senhores aqui analisados, atentemos para a trajetória e a memória senhorial da família Rocha, secularmente construídas.

\section{Os Rochas Abreu e os Josés da Rocha: alianças}

Em 1794, houve o casamento dos escravos Francisco, crioulo nascido em Porto Feliz, e Maria, crioula natural das minas de Cuiabá. Ambos filhos de pai incógnito e de mães escravas, e todos pertencentes ao padre André da Rocha Abreu. ${ }^{18}$ Uma das testemunhas do casamento foi Francisco Correa de Moraes Leite, outrora capitão-mor da vila de Porto Feliz durante 23 anos, entre 1797 e $1820 . .^{19}$ Os elos que ligavam o capitão aos nubentes cativos vêm de sua relação com o proprietário, o padre André, seu cunhado.

Os Rochas Abreu estavam ligados à rota das monções, via fluvial que ligava Porto Feliz à vila de Cuiabá, em Mato Grosso. Na primeira metade do setecentos, o pai do padre André, Domingos da Rocha Abreu, se transferiu

14 Segundo Grinberg, "talvez pela indisfarçável simpatia à causa abolicionista, talvez pela surpresa que as atuações dos escravos e os argumentos jurídicos favoráveis à liberdade ainda causam àqueles que lidam com este tipo de processo [ações de liberdade], o fato é que pouca atenção, até hoje, foi dada às práticas de re-escravização ocorridas no período, tanto através da revogação da alforria, quanto da escravização ilegal de descendentes de indígenas, de libertos ou de africanos chegados no Brasil após a lei de 1831, que proibia o tráfico atlântico de escravos (...) assim como foram abundantes as demandas de escravos pela liberdade na justiça no século XIX, também muitas foram as tentativas feitas por libertos de manter suas alforrias quando estas Ihes pareceram ameaçadas e muitos foram os casos nos quais os próprios senhores tentaram reaver a posse sobre antigos ou supostos escravos através dos tribunais (...)". GRINBERG, Keila. Reescravização, Direitos e Justiças no Brasil do Século XIX. In: Direitos e justiças no Brasil: ensaios de história social. Campinas: Editora da UNICAMP, 2006, p.101-128, p.103

15 CHALHOUB, Sidney. Visões da liberdade; CASTRO, Hebe. Das cores do silêncio.

16 Sobre a não linearidade em direção à liberdade, cf. XAVIER, Regina Célia. A conquista da liberdade. Libertos em Campinas na segunda metade do século XIX. Campinas: Centro de Memória/UNICAMP, 1996.

17 GRINBERG, Keila. Senhores sem escravos, p.12.

18 Arquivo da Cúria Diocesana de Sorocaba (ACDS), Casamento de Escravos, Livro 2 (1787-1821), f.22.

19 Arquivo do Estado de São Paulo. Lista Nominativa de Porto Feliz (LNPF), Anos de 1798 a 1820. 
do Arcebispado de Braga para São Paulo, onde se casou com D. Francisca Cardoso de Siqueira. Posteriormente, estabeleceu-se na freguesia de Araritaguaba (futura Porto Feliz em 1798), aí falecendo em 1784. Homem de "conhecida verdade", em 1767 era um dos cinco mais ricos da vila de Itu. De seu casamento com dona Francisca nasceram dez filhos, dos quais interessam aqui Ana Francisca da Rocha e o padre André da Rocha Abreu. ${ }^{20}$

Ana Francisca da Rocha se casou em 1782 com Francisco Correia de Moraes Leite, então apenas capitão de companhia. Em 1824, já como capitão-mor, de posse de 65 escravos, fez 1.600 arrobas de açúcar, 1.000 alqueires de milho, 150 de feijão e 40 de arroz. ${ }^{21}$ Um dos filhos do casal foi o brigadeiro Joaquim José de Moraes Abreu, que se tornou membro do Conselho da Província, vereador da Câmara Municipal de São Paulo, deputado provincial e vice-presidente da Província de São Paulo. ${ }^{22}$ Logo, é uma família de importância política e econômica em São Paulo, desde o século XVIII. Ramos dos Rochas forros se aliaram a esta família de potentados, mas uma aliança que começou quando ainda eram escravos. Por isso, o capitão foi o padrinho de casamento de Francisco e Maria, escravos do padre. Maria era natural de Cuiabá e era o capitão que organizava as expedições fluviais. Quiçá o sogro e os cunhados do capitão, comerciantes que atuavam na rota, trouxeram a cativa de Cuiabá. Por sua vez, o noivo, natural de Porto Feliz, deve ter nascido entre os Rochas, era cria da casa. Em 988 casamentos de escravos entre os anos de 1787 e 1833, ${ }^{23}$ o capitãomor só testemunhou dois. Em suma, provavelmente os nubentes conviviam com a família senhorial há muitos anos.

O outro filho de Domingos da Rocha Abreu que se estabeleceu em Porto Feliz foi o padre André da Rocha Abreu. Foi vigário de Porto Feliz entre 1798 e 1820, quando faleceu. Parodiava um verso quando comia bolo: "Destes bolinhos, Maria". Maria era também o nome de sua escrava cozinheira, provavelmente a que teve o capitão-mor como testemunha de casamento. Como gostava de folheado, o padre André ordenava à sua escrava cozinheira: "Maria, faça folhados, eu gosto, é como hóstia". Bom

20 GODOY, Silvana Alves de. Itu e Araritaguaba na rota das Monções (1718 a 1838). Campinas: Unicamp, 2002 (Economia, tese de mestrado); Revista do Instituto Histórico e Geográfico de São Paulo (RIHGSP), vol.VI, 1902, p.291-293; CAMPOS, J. Porto Feliz histórico. Itu: Editora Ottoni, 2003, p.115.

21 A propriedade do capitão-mor ampliou-se ao longo das décadas iniciais do século XIX. LNPF, Anos 1798, 2 Companhia, fogo 210. Doravante, abreviarei as citações das listas nominativas. Companhia será Cia., fogo será f. e Quarteirão, apenas Q. A citação obedecerá à seguinte ordem: nome, ano, companhia ou quarteirão/bairro e fogo (domicílio). As referências a uma mesma pessoa que aparece em mais de um ano serão separadas com ponto e vírgula. Por exemplo: Beltrano de Tal, 1815, $2^{\text {a }}$ Cia., f.90; 1820, $3^{\text {a }}$ Cia., f.10. Se o nome estiver no corpo do texto, suprimi-lo-ei na nota quando julgar necessário. Ocasionalmente, mencionarei os bairros. Demais referências

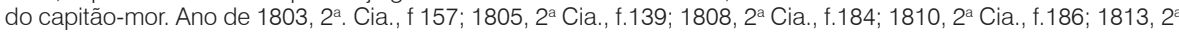

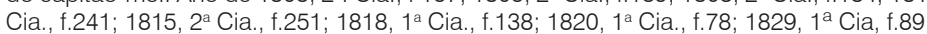

22 Godoy, Silvana. Itu e Araritaguaba, capítulo 3.

23 A morte do capitão foi aferida em seu testamento, aberto em 1833. MRCI. Pasta 107, doc 25. ACDS. Casamento de Escravos, Livro 2 (1787-1821) e Livro 3 (1821-1858). 
garfo, o padre sabia música e tocava piano. Pôs o primeiro piano na vila, instrumento conduzido por braço escravo de Santos a São Paulo. ${ }^{24}$

Em 1803, o reverendo André passou cartas de liberdade ao mencionado casal Francisco e Maria, e também a seus filhos Jesuíno, Celestina, Lucina, Generoso, Duarte e Benigno. ${ }^{25}$ Entre 1803 e 1820, o padre, em geral, libertava um membro de cada família que vivia consigo, precisamente a mulher. Os libertos de 1803 formavam a única família que teve todos os seus componentes alforriados desde então, o que a diferenciava de todas as demais subalternas ao reverendo. ${ }^{26}$ Por que o privilégio?

Provavelmente porque eram escravos domésticos. ${ }^{27}$ Maria devia ser a cozinheira que fazia pastéis com gosto de hóstia para o padre, alegrando seu estômago e seu espírito. Francisco e Maria foram dos primeiros escravos do padre a se casar e, um filho desse casal, Jesuíno, foi talvez o primeiro cativo nascido na casa, pois, em 1798, já tinha seis anos. Na verdade, outra família escrava, a do casal Domingos Velho e Joana, já estava junta em 1798 e também tinha um filho de seis anos. As diferenças sabidas entre os casais cativos são as seguintes. Francisco e Maria tinham mais filhos. ${ }^{28}$ Domingos Velho era Mina e Francisco nasceu em Araritaguaba (Porto Feliz), ou seja, o segundo devia ser criado na casa dos Rochas. Maria era natural de Cuiabá, para onde os cunhados do padre faziam expedições. Com 30 anos em 1798, talvez as relações de Maria com os Rochas fossem originárias de Cuiabá. Outra diferença é que o padrinho de casamento foi o capitão-mor.

A preferência do padre tornou os filhos de Francisco e Maria seus herdeiros em testamento de 1820. André disse que os criou com amor, sendo correspondido com servidão. ${ }^{29}$

Voltando a 1805, o reverendo André da Rocha, branco, contava 48 anos de idade. Tinha 17 escravos e, além de Jacinto, os demais agregados eram a família parda alforriada. Em 1808, com 51 anos, o vigário colado, sempre branco, tinha 15 escravos. Vivia com os agregados pardos e seus escravos negros. Em 1810, o padre André tinha 13 escravos. Os agregados permaneceram no domicílio, acrescido de duas novas agregadas, dentre as quais Maria, de um ano de idade.

24 RIHGSP, vol.VI, p.291-293, 1902.

25 LNPF. Ano de 1803, $2^{a}$ Cia., f.235. Parece que, para alguns, a doação das cartas de liberdades foi depois da liberdade de fato, já que Jesuíno, por exemplo, já era hóspede em 1798.

26 Nas listas nominativas, as referências sobre o domicílio do padre André da Rocha Abreu são LNPF, Ano, 1798, f.11; 1803, f.235; 1805, f.226; 1808, f.261; 1810, f.272; 1813, f.337; 1815, f.338; 1818, f.191. Sempre na $2^{\mathrm{a}}$ Cia. Salvo indicação contrária, o que segue sobre seus escravos e agregados também foi retirado dessas referências.

27 O que designo como doméstico se deve menos à ocupação e mais à inserção na convivência senhorial. Vide GÓES, José Roberto e FLORENTINO, Manolo. A paz das senzalas: famílias escravas e tráfico atlântico. Rio de Janeiro, 1790-1850. Rio de Janeiro: Civilização Brasileira, 1997, p.105.

28 Há indicações de que cativos mais aparentados tinham mais chances de acesso a legados e heranças de seus senhores. Cf. HARTUNG, Miriam. Muito além do céu: escravidão e estratégias de liberdade no Paraná do século XIX. Topoi. Revista de História, Rio de Janeiro, n.10, v.6, p.160-82, 2005.

$29 \mathrm{MRCl}$. Pasta 348, s.n. Testamento do padre André da Rocha Abreu. 
Esta Maria foi registrada como escrava no batismo, em 06 de agosto de 1809, apesar de o assento ter sido feito no livro de livres. Era "filha de Francisco, escravo do Reverendo Vigário André da Rocha Abreu", sem referência ao nome da mãe. O assento foi redigido pelo padre Manoel Ferraz Sampaio, mas, no canto, à margem da folha, lê-se: a "batizada Maria é filha de Francisco e Maria, sua mulher. Todos estão forros e libertos", assinado pelo padre André da Rocha Abreu. Portanto, além de atestar a maternidade, corrigiu o assento para referendar a condição de forro de Francisco e de Maria. Como André tomou ciência do equívoco em meio a tantos registros fica por se saber. ${ }^{30} \mathrm{O}$ fato é que continuou amparando seus agregados no jogo da troca das relações entre senhores e subalternos, já que, em uma sociedade escravista, ser registrado como livre ou escravo num livro paroquial é de suma importância, pois pode definir a condição jurídica das pessoas. Todavia, 55 anos depois, em 1864, no auto de liberdade, aquele mesmo João de Camargo do início deste artigo, casado com uma Rocha, sobrepôs ao registro de batismo uma escritura pública de doação de escravos como prova; doação escrita pelo próprio padre André, registrada em cartório.

De retorno ao padre André e seus subalternos, em 1813 ele estava com 57 anos de idade e 15 escravos. Os pardos forros permaneciam como dantes e só se acrescentou que um deles, Jesuíno, era "organista". ${ }^{31}$ Em 1815, o padre era também senhor de engenho e de 16 escravos. Os agregados pardos estavam acompanhados de Francisco, o único negro entre eles, recém-alforriado. Em 1818, André da Rocha Abreu tinha 62 anos. Seus agregados pardos forros de antes permaneciam no domicílio. Havia apenas cinco escravos em sua casa.

Até aqui o que se observa entre os escravos e agregados, em suas relações com André, é que estavam em uma cadeia diferenciada de privilégios e exclusões, em uma política de domínio que distinguia os merecedores e os não merecedores de prêmios. ${ }^{32}$ Toda uma família foi alforriada desde 1803 e amparada pelo padre quando esta condição foi posta em dúvida em um batismo. Em tempo, não se deve esquecer que, em tese pelo menos, ser forro implica em trabalhar para si, ainda que trabalhador livre não seja sinônimo de trabalho autônomo. ${ }^{33}$ Significa também uma diferenciação jurídica em uma sociedade escravista, ou seja, alforria é mobilidade social

30 Parece que os livros paroquiais eram revisados ao fim de cada ano com vistas a prestar informações para a elaboração das listas nominativas. Em 1824, um padre respondia ao capitão-mor sobre o número de nascimentos, casamentos e óbitos da vila. LNPF, 1824. A referência do batismo é ACDS. Batismo de Livres. Livro 1 A (1807-1819), f.27v.

31 Organista é a "pessoa que toca órgão, instrumento". SILVA, Antônio de Moraes e. Dicionário da língua portuguesa. $2^{\mathrm{a}}$.ed. Lisboa: Tipografia Lacerdina, 1813.

32 Cf. SLENES, Robert. Senhores e subalternos no Oeste Paulista. In: ALENCASTRO, Luiz Felipe de. (org.) História da vida privada no Brasil. São Paulo: Companhia das Letras, v.2, 1997, p.233-290.

33 A respeito da coação ao trabalhador livre, cf. MAMIGONIAN, Beatriz. Revisitando a 'transição para o trabalho livre': a experiência dos africanos livres. In: FLORENTINO, Manolo. (org.) Tráfico, cativeiro e liberdade (Rio de Janeiro, séculos XVII-XIX). Rio de Janeiro: Civilização Brasileira, 2005, p.389-417. 
ascendente. Os agregados do padre, ao saírem do cativeiro, até mudavam de cor, tornaram-se pardos, deixaram de ser negros. Isto fazia diferença, posto que ser pardo já implicava um distanciamento em relação à escravidão. Um ideal hierárquico calcado na cor/condição social. ${ }^{34}$

Os demais escravos do vigário não tiveram a mesma sorte. Alguns continuaram em cativeiro; outros foram libertos, mas membros de suas famílias continuaram na escravidão. Alguns foram doados à família parda alforriada. Foi isso que, em 1864, João Leite de Camargo argumentou para manter o domínio sobre o afilhado de Rosa, José, filho de Generosa. Mas quem era Generosa? Nada se sabe sobre seus parentes. A única informação é que o padre André a doou à "mulatinha" Esmelinda, em 1820. Então, a "mulatinha" contava cerca de 23 anos de idade, e a cativa Generosa, dois anos. Esmelinda casou-se com o réu em 1827. ${ }^{35}$ Quem sabe Generosa ajudou a compor seu dote? A certeza é que para continuarem como senhores em 1864 era preciso manter José, filho de Generosa, em cativeiro. No contexto de fechamento do acesso à mão-de-obra via comércio de escravos, a perpetuação da condição senhorial de uma família forra dependia da continuidade da escravidão de uma família escrava.

\section{A Morte do Padre e os Destinos de Seus Escravos e Agregados}

Em 1820, o vigário André da Rocha Abreu morreu, aos 63 anos. Sem herdeiros forçados, o padre instituiu como tais, em testamento de 1819, os filhos da antiga família de agregados forros:

Declaro que sou natural desta vila de Porto Feliz e nela Vigário Colado, filho legítimo de Domingos da Rocha Abreu e dona Francisca Cardoso de Siqueira, ambos já falecidos (...) não tenho herdeiros forçados; portanto, é disposição de minha última vontade instituir (...) por meus universais herdeiros, de tudo o que resta de meus bens (...) ao primeiro testamenteiro [1] Jesuíno José da Rocha, e a todos os seus irmãos e irmãs, a saber, [2] Generoso, [3] Duarte, [4] Benigno, [5] Celestina, [6] Lucinda, [7] Maria e [8] Esmelinda, visto que quase todos foram meus escravos, que eu os forrei, e a todos criei com amor, e eles com igual correspondência me estão servindo. Declaro mais que aos sobreditos meus herdeiros (...) já fiz em minha vida algumas doações (...) e esses bens

34 Abordamos o tópico da mudança de cor em GUEDES, Roberto. Sociedade escravista e mudança de cor. Porto Feliz, São Paulo, Século XIX. In: SAMPAIO, Antonio Carlos Jucá et alli (orgs.) Nas rotas do Império: eixos mercantis, tráfico de escravos e relações sociais no mundo português. Vitória/Lisboa: EDUFES/IICTP, 2006, v.1, p.447-488; GUEDES, Roberto. De ex-escravo à elite escravista: a trajetória de ascensão social do pardo alferes Joaquim Barbosa Neves (Porto Feliz, São Paulo, Século XIX). In: FRAGOSO João; ALMEIDA, Carla; SAMPAIO, Antonio Carlos Jucá. (orgs.) Conquistadores e negociantes: história de elites no Antigo Regime nos trópicos, América Lusa, séculos XVI a XVIII. Rio de Janeiro: Civilização Brasileira, 2007, p.337-376; GUEDES, Roberto. Estratégias de mobilidade social em sociedades escravistas. Uma análise comparada (Porto Feliz/São Paulo/Brasil e Torbee/São Domingos, sécs. XVIII e XIX). Revista Fronteiras, Campo Grande, v.10, p.51-93, 2008; GUEDES, Roberto. Escravidão e cor nos censos de Porto Feliz (São Paulo, século XIX). Revista Especiaria, Ilhéus, v.10, 2009, p.489-518.

35 Em 1798, Esmelinda tinha 3 anos de idade. ACDS. Casamento de livres, Livro 4 (1818-1837), f.78. 
se não confundirão com os meus. E, portanto (...) todos os remanescentes de meus bens serão repartidos em igual parte pelos sobreditos meus herdeiros. ${ }^{36}$

Todos os herdeiros eram filhos de Francisco da Rocha e de Maria Francisca da Rocha; estes os nomes completos dos nubentes que tiveram como testemunha de casamento o capitão-mor. Os filhos masculinos do casal passaram a ser nomeados com os sobrenomes José Rocha, e Maria da Rocha para as mulheres. Porém, o padre frisou apenas o nome completo de Jesuíno José da Rocha, sem dúvida o mais privilegiado por suas doações e pela política diferenciada de incentivos do reverendo. Jesuíno foi seu primeiro testamenteiro e era organista desde 1813. Este Jesuíno é o pai do filho homônimo; filho que sofreu o processo de ação de manutenção de liberdade movido pela escrava Firmina e seus filhos menores, em 1878.

$\mathrm{Na}$ verdade, os escravos e agregados que viviam em torno de André formavam uma comunidade organizada em núcleos familiares. Para este artigo, importa observar o núcleo que permaneceu cativo e o que foi privilegiado, aqui designados como ramos escravizado e senhorial. O ramo escravizado inicia-se com (1) Domingos Velho e (2) Joana, cativa que se casou em segundas núpcias com (3) Fortunato. Entre 1820 e 1824, (3) Fortunato era agregado do herdeiro Jesuíno José da Rocha, assim como (2) Joana, sua esposa, viúva de (1) Domingos Velho, e (4) a menina Maria. Fortunato e Joana não foram libertados no testamento de André e tampouco encontrados em alforrias cartoriais, ${ }^{37}$ mas o fato de serem agregados em 1820, ano da morte do padre, atesta que receberam alforria. Em domicilio próprio, Fortunato Rocha, negro, era pedreiro em 1829, com 59 anos de idade. Acompanhava-o Joana e um filho, (5) André, depois André da Rocha, de 17 anos. Todos negros. ${ }^{38}$ André da Rocha casou com Antonia Nobre em 1834, ambos libertos. ${ }^{39}$

Continuando no ramo cativo, há outro filho de Joana com Domingos Velho, (6) Abraão, que em 1822 se casou com a escrava (7) Mariana. Ele chegou à alforria, mas a esposa, não. Em 1829, ela ainda era escrava de Jesuíno José da Rocha e ele vivia como agregado. Ademais, em 1834 apadrinharam uma menina, quando Mariana ainda era cativa de Jesuíno, e não se fez alusão à condição jurídica do padrinho. Em dezembro do mesmo ano, ele novamente foi padrinho, também sem destaque de sua condição jurídica. ${ }^{40}$ Abraão faleceu em dezembro de 1836, aos 40 anos de idade, sendo enterrado no cemitério da Irmandade de São Benedito. ${ }^{41}$ Mariana,

\footnotetext{
$36 \mathrm{MRCl}$. Pasta 348, s.n. Testamento do Padre André da Rocha Abreu.

37 Consultamos mais de dez livros de notas. MRCl. Pastas 173 a 185

38 LNPF. Ano 1829, $2^{\text {a }}$ Cia., f.56.

39 ACDS. Casamento de Livres, Livro 4 (1818-1837), f.123.

40 ACDS. Batismo de Livres, Livro 5 (1834-1846), f.6 e 10.

41 ACDS. Livro de Óbito de Brancos e Libertos (1834-1866), f.12v.
} 
viúva de Abraão, casou, em outubro de 1837, com (8) Caetano, ${ }^{42}$ gentio da Guiné, escravos de Feliciana Maria de Jesus, viúva de Jesuíno José da Rocha, falecido em 1836.

Em resumo, Abraão foi escravo de André, escravo e agregado de Jesuíno, e "agregado" de Feliciana. Uma longa história de submissão ${ }^{43}$ de um membro do ramo escravizado para com o ramo de senhores Rochas.

Ainda no ramo escravizado, há outro filho do casal (1) Domingos Velho e (2) Joana, também denominado (9) Domingos. Foi escravo do padre de 1798 a 1818 e, de 1820 a 1824, de Jesuíno. Em novembro de 1819, Domingos casou com (10) Teodora Crioula, escravos de Jesuíno. ${ }^{44}$ Domingos se tornou Domingos da Rocha e registrou sua carta de liberdade em 26 de maio de 1830, passada em 06 de outubro de 1828, na qual Jesuíno José da Rocha afirmava que era senhor de um "crioulo de nome Domingos, casado, de idade de 30 anos". Disse que o escravo Ihe foi doado pelo padre André com a condição de que, quando pagasse 120 mil réis, deveria ser-lhe passada carta de liberdade. ${ }^{45}$ Quase 5 anos depois, o novo liberto já estava morto, pois em 18 de março de 1835, Teodora, crioula, viúva de Domingos, casouse com (11) Antônio, gentio da Guiné, escravo de dona Feliciana Maria de Jesus. ${ }^{46}$ Da trajetória de Domingos da Rocha, nota-se que seu segundo senhor, Jesuíno Rocha, o recebeu como legado do padre. Trabalhou para este privilegiado forro por quase dez anos, pelo menos quatro anos como escravo, e os demais para pagar por sua alforria. Ao casar com Teodora, escrava de dona Feliciana (viúva de Jesuíno), Domingos continuou na órbita de submissão para com os forros senhores Rocha.

Por fim, (12) Samuel da Rocha, também filho de (1) Domingos Velho e (2) Joana. Foi escravo do padre de 1803 a 1815 e, em 1826, apadrinhou um afilhado ainda como escravo, isto é, permaneceu com o senhor herdeiro Jesuíno José da Rocha. Entre 1836 e 1843, era carpinteiro negro. Seus ditames testamentais de abril de 1860 contam um pouco de sua vida:

Eu, Samuel da Rocha, (...) declaro que sou natural desta cidade, filho de Domingos e Joana, já falecidos (...) casado com Rosa de Arruda, de cujo matrimonio não tivemos filhos algum, e não tendo por isso herdeiros necessários instituo por minha única herdeira a dita minha mulher; declaro que devo a minha comadre Cândida, escrava de Joaquim de Toledo, a quantia de 400 mil reis; declaro que deixo liberto o meu escravo João com a condição dele pagar a dita minha comadre (...) declaro que deixo à Irmandade de São Benedito a quantia de dezesseis mil reis, e igual quantia à Irmandade de Nossa Senhora da Boa Morte; e

42 ACDS. Casamento de Escravos, Livro 3 (1821-1858), f.78v.

43 Evidente que nem toda forma de agregação pressupõe dependência e submissão. Sobre o aspecto, vide MACHADO, Cacilda . A trama das vontades: negros, pardos e brancos na construção da hierarquia social do Brasil escravista. Rio de Janeiro: Apicuri, 2008.

44 ACDS. Casamento de Escravos, Livro 2 (1787-1818), f.85v.

$45 \mathrm{MRCl}$. Livro de Notas, Pasta 176, Livro 12, f.43.

46 ACDS. Casamento de Escravos, Livro 3 (1821-1858), f.71v. 
a mesma quantia para a Igreja de Nossa Senhora Mãe dos Homens (...) declaro que deixo a minha ferramenta de carpinteiro para o meu escravo João; rogo queiram ser meus testamenteiros em primeiro lugar a minha mulher (...) e por essa forma dou por concluído (...) e a meu rogo assinado por (...) eu não saber escrever. Porto Feliz, [abril de 1860]. ${ }^{47}$

Da trajetória de Samuel, podem-se observar alguns aspectos comuns a forros. Nasceu em cativeiro e permaneceu escravo até seus cerca de 20 anos, passado de um proprietário a outro de uma mesma família senhorial. Foi o destino de outros membros de sua família, como os de seus irmãos Domingos e Abraão. Era carpinteiro. Em 1862, seu inventário somava em bens 2:832\$000 (2 contos e 832 mil réis), incluindo uma casa, dois terrenos e um escravo. Devia apenas $114 \$ 000$ réis e tinha $120 \$ 000$ em dinheiro. ${ }^{48}$ Participava das instâncias de socialização e de religiosidade de libertos, como as irmandades de negros e pardos de Nossa Senhora da Boa Morte e de São Benedito, às quais deixou legados, bem como à Igreja Matriz. Apadrinhou nove crianças entre 1826 e 1857, seis vezes com sua mulher, Rosa Maria de Arruda. Seus afilhados eram quatro filhos de pai incógnito e cinco de casais sem título algum. ${ }^{49}$ Também estabeleceu laços de parentesco ritual com uma escrava, a comadre a quem devia. Devia também a um "escravo de Francisco de Arruda", como consta em seu inventário. Senhor de escravo, para ele a nova condição não significou o afastamento em relação a escravos e outros egressos do cativeiro. Outrossim, acreditou que o trabalho conduzia à alforria, ou seja, o trabalho propiciava meios de (re)inserção social para (ex)escravos, inclusive para o pagamento da liberdade. Por isso deu a ferramenta de carpintaria a seu cativo e a alforria condicionada a pagamento. Por outro lado, o carpinteiro negro Samuel Rocha era chefe de fogo em 1836 e 1843, quando ainda não tinha escravo, ${ }^{50} \mathrm{O}$ que significa que deve ter comprado seu cativo com o suor de seu próprio trabalho. Reproduziu a escravidão com o seu ofício de carpinteiro, aprendido a duras penas na época em que era escravo. Logo, a experiência de trabalho em cativeiro trazida para a vida em liberdade contribuiu para preservar a escravidão.

Dois anos depois de sua morte, em 1864, mesmo considerando todo o esforço de Samuel para reiterar a escravidão, nada impediu sua esposa, Rosa Maria de Arruda, aquela mesma do iníncio deste artigo, de mover uma ação em prol da liberdade de seu afilhado e contra um membro da família de forros senhores Rochas. Nenhuma contradição de Rosa, pois a escravidão

$47 \mathrm{MRCl}$. Pasta 343, s.n. Testamento de Samuel da Rocha.

48 MRCI. Pasta 293, doc.6. Inventário de Samuel da Rocha.

49 ACDS. Batismo de Livres, Livro 2-A (1825-1829), f.33; Livro 5 (1834-1846), f.53v., 116, 125 e 193; Livro 6 (18461860), fl 32v.; 60v.; 87 e 157. A condição de escravo se encontra no primeiro batismo e a de forro, no quarto.

50 Ano 1836, Q.1, f.19; 1843, Q.2 da Vila, f.147. 
de João, cativo de seu marido, não era a de nenhum parente seu. Mas era dever de madrinha proteger e libertar seu afilhado. Além disso, seu marido, seus cunhados, seus sogros foram todos escravos da família Rocha durante vários anos, e submeterem-se também como agregados. ${ }^{51}$ Seus parentes foram legados a Jesuíno José da Rocha, de longa data beneficiado pelo padre André, de quem herdou terras, o engenho, os escravos e a dependência de certos agregados. Aliás, dois cunhados de Rosa, Domingos e Abraão, ainda foram agregados de dona Feliciana Maria de Jesus.

Quanto rancor e memória do cativeiro e da subserviência de seus parentes devem ter influenciado Rosa a impetrar o auto judicial de manutenção de liberdade contra João Leite de Camargo, marido de Esmelida Maria da Rocha, cunhado de Jesuíno José da Rocha e concunhado de Feliciana Maria de Jesus?! Como o marido de Rosa disse em testamento, o casal não tinha filhos. A ação judicial foi motivada pelo dever de madrinha para com seu afilhado. Tratar-se-ia de mais um parente seu a continuar escravo ou agregado dos Rochas. Desta vez um parente espiritual, o que talvez Rosa, viúva sem filhos, não suportasse..$^{52}$

De outra parte, para a família do réu, a causa de liberdade romperia com uma longa história de submissão de uma família a outra, pois sua condição senhorial também tem uma trajetória e a construção de uma identidade, cujo processo de elaboração analisaremos a seguir.

\section{De forros agregados do padre André a proprietários: o ramo senhorial}

Como vimos, o patriarca forro e sua esposa, Francisco da Rocha e Maria Francisca da Rocha, receberam carta de liberdade em 1803 e talvez fossem escravos domésticos. Depois da morte de André, Francisco era oficial de sapateiro pardo e o casal chegou a ter 5 escravos entre 1820 e 1829. Em 1836, ambos estavam mortos. Os filhos do casal tinham os nomes completos de Jesuíno José da Rocha, Benigno Antônio Boussuet (ou Benigno Antônio da Rocha), Generoso José da Rocha, Lucinda Maria da Rocha, Celestina Maria da Rocha e Esmelinda Maria da Rocha. Suas reinserções

51 Evidentemente, submissão, entendida como reconhecimento de um poder senhorial, e dependência não são sinônimos de exclusão social. Como já salientamos, é preciso atentar para o interesse do dependente pela dependência e do submisso pelo submissão. Podem ser estratégias para conseguir recursos materiais, simbólicos, políticos, etc. em meio a um mundo de incertezas. GUEDES, Roberto. Egressos do cativeiro: trabalho, família, aliança e mobilidade social (Porto Feliz, São Paulo, c.1798-c.1850). Rio de Janeiro: FAPERJ/MAUAD, 2008.

52 Em sociedades de base cristã, a paternidade e a maternidade espiritual, representada pelos padrinhos, têm primazia sobre as biológicas. ARANTES, Antônio A. Pais, padrinhos e o Espírito Santo. In: CORREA A, Mariza et alli. (orgs.) Colcha de retalhos: estudos sobre a família no Brasil. Campinas: Editora da UNICAMP, 1994. Vide também CAMPOS, Adalgisa Arantes e FRANCO, Renato Júnior. Notas sobre os significados religiosos do Batismo. Revista Varia Historia, Belo Horizonte, v.31, p.21-40, 2004. Sobre pegar mal deixar filhos, mesmo ilegítimos, em cativeiro, cf. SOARES, Márcio de Sousa. A remissão do cativeiro: a dádiva da alforria e o governo dos escravos nos Campos dos Goitacases, c.1750 - c.1830. Rio de Janeiro: Apicuri, 2009. 
sociais foram feitas com base nos legados senhoriais do padre André: o nome, a condição senhorial, as relações sociais e os bens materiais. Tudo teve de ser reatualizado pelos ex-escravos senhores.

\section{Nome de senhor}

Em primeiro lugar, a herança do nome e do sobrenome,,$^{53}$ que acompanham o indivíduo em toda sua vida, ${ }^{54}$ mas, no Brasil de outrora, acompanhavam a família. Ao incorporar um sobrenome de André, os herdeiros carregaram um pouco de seu prestígio, de sua identidade e de suas relações sociais, heranças imateriais. ${ }^{55} \mathrm{O}$ sobrenome Rocha remontava à proeminente família ituana do século XVIII, que estava entre as mais ricas da vila e, mais importante, o pai fundador setecentista era "homem de conhecida verdade". Sem esquecer que a testemunha das núpcias do casal forro era o capitão casado com uma Rocha. E o próprio padre André era vigário colado entre 1798 e 1820.

O legado do nome e seu significado senhorial, porém, foram reconstruídos pelos Rochas libertos, talvez para se diferenciarem de outros egressos do cativeiro e de livres, sem vínculos mais sólidos com as elites. A propósito, Jesuíno, beneficiado entre seus irmãos, batizou seu primeiro filho com o nome de André, em homenagem ao padre. Pode haver aí uma hierarquia no interior da própria família forra privilegiada, mas nem por isso suas práticas de nomeação deixaram de se reportar ao sentimento de identidade familiar senhorial herdada do padre, perpetuado nas gerações seguintes. ${ }^{56}$ As três irmãs de Jesuíno, além de Maria, têm o Rocha, como a mãe. O José, de Generoso e do beneficiado Jesuíno, é de origem incerta, mas o Rocha, Jesuíno reproduziu em seus filhos. Generoso também pôs este sobrenome em seu filho Prudente Marques Rocha, ou quiçá tenha sido o próprio filho, posto que Generoso cedo ficou órfão de pai. De qualquer modo, há que se levar em conta que no ato do batismo informa-se apenas o primeiro nome do batizado, e o sobrenome é construído ao longo da vida em função das identidades familiares e sociais que se quer carregar. ${ }^{57}$

Benigno, ainda na segunda geração, foi o único que não teve filhos e também não usava o sobrenome Rocha, só aparecendo com ele em três

53 Sobrenome significa o nome, ou apelido, que se junta ao nome de batismo. Nome é o substantivo, ou parte da Oração, com que damos a conhecer, e significamos os indivíduos. SILVA, Antônio de Moraes e. Discionário. Sobre forros que incorporavam o nome do antigo senhor para referendar sua nova posição social, vide SOARES, Márcio de Sousa. Fortunas mestiças: perfilhação de escravos, herança e mobilidade social de forros em Campos dos Goitacases no alvorecer do oitocentos. Revista Estudos de História, Franca, n.2, v.9, p.165-194, 2002.

54 GINZBURG, Carlo. A micro-história e outros ensaios. Lisboa: Difel, 1991, p.173-175.

55 Veja o caso de tentativa de reiteração de legado imaterial em LEVI, Giovani. A herança imaterial.

56 Uso a palavra geração no sentido empírico, não antropológico.

57 Cf. HAMEISTER, Martha Daisson. Para dar calor à nova povoação: estudo sobre estratégias sociais e familiares a partir dos registros batismais da vila do Rio Grande (1738-1763). Rio de Janeiro: UFRJ, 2006, cap.3. (História, tese de mestrado). 
ocasiões. A primeira, em 1844, ao assinar recibo de legados deixados por seu irmão Jesuíno. Até então, "Benigno Antônio Boussuet" vivia agregado a seu sogro, ou melhor, desde o seu casamento, em 1824, até 1829. Só passou a usar o nome Rocha depois de 1836, quando desfez sua "sociedade conjugal de bens" e "coabitação" e retornou ao convívio de sua mãe, de quem foi inventariante. A terceira vez foi em 1857, quando, aos 40 anos, foi sepultado como Benigno Antônio da Rocha. ${ }^{58}$ Como o defunto não escolheu nome e sobrenome, sua família se encarregou de nomear a condição senhorial no além-túmulo.

Mas também para a vida terrena os sentimentos de família se expressavam na nomeação dos filhos dos irmãos da segunda e terceira gerações. ${ }^{59}$ Desconsiderando as Anas, nomes provavelmente escolhidos pelas madrinhas xarás, os demais nomes dos batizados não tinham nada a ver com os de seus padrinhos, mas havia três Carolinas, três Joaquins, em homenagem aos pais, três Marias, dois Augustos e uma Augusta, dois Josés e dois Mâncios e dois Franciscos, tributando o (bis)avô. Estes nomes circulam os núcleos familiares dos Rocha. Poder-se-ia dizer que eram escolhas fortuitas, mas eram atitudes intencionais. Entre os primos, membros da terceira e quarta gerações, quase metade tinha nomes em comum. Além disto, só havia um Manoel, e não há Pedro, Paulo, Bento, Gertrudes, Mariana, Joaquina, Josefa, Luiza, etc., nomes bastante comuns na época. Portanto, o sentimento de família era latente entre os Rochas e a prática de nomeação era uma forma de identificá-los como parentes, para além dos núcleos familiares. Uma parentela de forros senhores trazendo no nome, ao longo das gerações, uma memória de moblidade social de agregados a senhores.

As relações sociais herdadas do padre também foram parcialmente reconstruídas.

\section{Os José Rocha e seus compadres ${ }^{60}$}

Os laços de compadrio dos Rochas demonstram que utilizaram a pia batismal para dar continuidade a relações sociais legadas pelo padre, e tecer novas alianças. Nenhum irmão apadrinhou filho de outro e, por isto, os elos se realizaram preferencialmente fora dos núcleos familiares da segunda e terceira gerações. As afeições internas se manifestaram, porém, pela avó Maria Francisca da Rocha, que foi madrinha de seis netos, e pelo avô,

58 LNPF. Antônio Pinheiro. Ano 1813; $2^{\mathrm{a}}$ Cia., f.73; 1815; $2^{\mathrm{a}}$ Cia., f.115; 1818; $2^{\mathrm{a}}$ Cia., f.47; 1820; $2^{\mathrm{a}}$ Cia., f.38; 1824; $2^{\mathrm{a}}$ Cia., f.75; 1829; $2^{a}$ Cia., f.26. Ver também Inventário de Antônio Pinheiro, MRCl. Pasta 244, doc.1; Livro de Óbito de Brancos e Libertos (1834-1866), f.57. Para o divórcio de Benigno, vide MRCI, Pasta 176, Livro 14.

59 Nomes aferidos pelos registros paroquiais da família. Vide Anexo 1.

60 As referências documentais para os laços de compadresco dos filhos dos Rochas forros estão no Anexo 1. 
Francisco da Rocha, padrinho de dois. Assim, o compadrio complementa e reforça uma relação parental anterior, hierarquizada pela ascendência.

Sobre os laços de compadrio externos a parentela, também se observa hierarquia. Na maioria das vezes, os filhos dos forros senhores eram apadrinhados por donas, tenentes, capitães, alferes, sargentos, vigários. Quiçá, prestaram serviços, recebendo em troca auxílios, proteção, benesses, etc. Nenhum dos homens Rocha foi listado como soldado. O não ser recrutado viabilizava a manutenção do homem no domicílio, força de trabalho e segurança. Portanto, no vai-e-vem das trocas, a retribuição de prestações era fundamental, mas as alianças tinham de ser constantemente refeitas e, para isto, o batismo prestou. Os elos de compadresco chegaram a atar os Rochas a diferentes gerações de padrinhos de uma mesma família.

Um exemplo de relações herdadas direta ou indiretamente do padre, embora não de compadrio, se expressa na pessoa de Francisco Antônio Carvalho. Menos de dois meses depois de ter sido nomeado como curador do escravo José, afilhado de Rosa Arruda, Francsico Antônio de Carvalho pediu ao juiz municipal, em fevereiro de 1865, para ser exonerado da função. Alegou que era "efetivamente" empregado nas obras da Igreja Matriz da cidade, o que o atrapalharia a cuidar dos direitos de José. Ele não explicita se a falta de zelo deriva do excesso de trabalho nas obras, mas não é difícil enxergar aí uma certa influência dos Rochas na Matriz. O padre fora vigário colado até 1820. Jesuíno José da Rocha, o pai, era organista até 1836. A propósito do legado de uma certa influência na Matriz, o padre José llidro Rodrigues testemunhou a favor dos Rochas no processo contra Jesuíno Filho em 1878. Nenhum padre testemunhou a favor da cativa Firmina.

De outro modo os elos de parentesco espiritual de determinados Rochas forros também se dirigiram a prováveis egressos do cativeiro, tendo em vista que não serviram como padrinhos de filhos de nenhuma pessoa com título. Mas parece que os laços entre forros não se reproduziram no tempo, eram mais pontuais, quiçá pela dificuldade de encontrar pessoas com ascendência escrava nas fontes. Porém, Generoso José da Rocha e sua mãe, Maria da Rocha, como padrinhos, batizaram, em 1828, dois filhos naturais de pai incógnito e de mãe solteira. Apadrinharam também uma menina, filha de um pardo jornaleiro lavrador. ${ }^{61}$ Entre 1825 e 1833, Generoso foi testemunha de seis casamentos de escravos, um dos quais de cativos de seu irmão, o senhor de engenho Jesuíno. ${ }^{62}$ Ainda dentre os Rochas da segunda geração, Celestina Maria, junto a seu marido, Joaquim Rodrigues Viana, apadrinhou, entre 1827 e 1850, três filhos legítimos cujos pais não

61 ACDS. Batismo de Livres, Livro 2-A (1825-1829), f.64v e 85v; LNPF. 1829, 4ª Cia, f.48; 1836, Q.4, f.35; 1843, Q.1, f.38.

62 ACDS. Casamento de Escravos, Livro 2 (1787-1821), f.83; Livro 3 (1821-1858), f.23v, 47v, 50 e 64. 
tinham título algum. ${ }^{63}$ Viana ainda testemunhou três casamentos de escravos entre 1816 e 1833, sendo um o de Abraão e Maria, escravos de seu cunhado Jesuíno José da Rocha. ${ }^{64}$ Em 1821, Lucinda Maria da Rocha e seu marido Joaquim Toledo serviram de padrinhos a uma menina de pais sem título. ${ }^{65}$

Ora, é sugestivo o fato de os ramos familiares senhoriais dos Rochas que foram processados pelos escravos nas décadas de 1860 e 1870 nunca terem sido padrinhos de escravos ou agregados que giravam na órbita dos Rochas senhores forros. Os Jesuínos pai e filho, dona Feliciana Maria de Jesus (viúva de Jesuíno Pai) e o casal Esmelinda Maria da Rocha e João Leite de Camargo (processado em 1864), não apadrinharam nenhum cativo ou forro e sequer foram testemunhas de casamento escravo. No processo contra Jesuíno Filho em 1878, uma das testemunhas a favor dos escravos foi enfática ao afirmar:

Não Ihe consta que alguém exercesse o poder dominical sobre Firmina e seus filhos, que conhece a todos os filhos de dona Feliciana e acredita que eles não se importavam com Firmina e seus filhos Josefina e Cândido, não sabendo se dava-se o mesmo em relação à Senhora dona Feliciana.

Não responderemos à pergunta contrafactual sobre se Jesuíno Filho fosse compadre de Firmina, o processo não ocorreria. Ela supõe o parentesco como algo meramente funcional e a não realização de conflitos entre parentes, mesmo os espirituais. O certo, porém, é que para manter o poder dominical era preciso se importar com os subalternos e os ramos processados não levaram isto a sério.

Por outro lado, os vínculos de parentesco ritual dos irmãos da segunda e terceira gerações com padrinhos de elite duravam anos, ou seja, as alianças eram reatadas, estáveis no tempo. O compadresco era geracional. Por exemplo, os laços com a família de padrinhos constituída pelo capitão José Manoel Arruda e dona Ana Manoela Moraes, pela filha e pelo genro desse casal. Os pais apadrinharam uma filha de Lucinda Rocha, em 1825, e um rebento de Celestina, em 1826. Dez anos depois, em 1836, a filha do casal, Ana Esméria Arruda, ainda solteira, batizou outra filha de Celestina rocha. Em 1841 e 1850, a mesma Ana Esméria, então casada com Francisco Correa de Toledo, apadrinha um filho de Prudente. Ou seja, a terceira e quarta gerações dos Rochas deram continuidade a elos construídos há 25 anos $^{66}$ Como muito bem sublinhou Silvia Brügger, o compadresco era uma relação entre famílias, não entre indivíduos. ${ }^{67}$

63 ACDS. Batismo de Livres, Livro 2-A (1825-1829), f.44; Livro 5 (1834-1846), f.56v; Livro 6 (1846-1860), f.61.

64 ACDS. Casamento de Escravos, Livro 2 (1787-1821), f.70; Livro 3 (1821-1858), f.11v e 66v.

65 ACDS. Batismo de Livres, Livro 1-A, f.49.

66 As referências documentais sobre os compadres dos Rochas forros estão no Anexo 2.

67 BRÜGGER, Silvia Maria Jardim. Escolhas de padrinhos e relações de poder: uma análise do compadrio em São João del Rei (1736-1850). In: CARVALHO, José Murilo de. (org.) Nação e cidadania no Império: novos horizontes. 
Um outro exemplo é o caso do que atou Francisco Antônio de Moraes Abreu (aquele mesmo filho do antigo capitão-mor da vila, vice-presidente de província) aos Rocha, nas ocasiões em que foi padrinho de dois rebentos de Esmelinda. Sendo filho do capitão-mor, Moraes Abreu é sobrinho do padre André da Rocha Abreu. Seu pai, o capitão-mor, foi testemunha de casamento dos pais de Esmelinda em 1794. Isto significa que a primeira geração de potentados testemunhou o casamento da família forra Rocha quando ainda era escrava. A segunda geração de potentados apadrinhou o neto. Ao se tornar comadre de Moraes Abreu, Esmelinda colaborou para que os Rochas reconstruíssem relações sociais pretéritas na mesma órbita da família de potentados. Tudo indica que o ramo da família Esmelinda Rocha, que não apadrinhou nenhum escravo da órbita dos forros Rochas, se aproximou mais das elites locais. O marido de Esmelinda Maria da Rocha foi quem sofreu o processo cível de ação de liberdade movido por Rosa Arruda em 1864.

Aliás, Moraes Abreu, o compadre de Esmelinda, também era o primeiro testamenteiro da matriarca dos Rochas forros, Maria Francisca, que o chamou de "Senhor Capitão", reconhecendo a proeminência da família potentada, no tempo. Jesuíno Pai o constitui, em testamento, como procurador em São Paulo. Assim, as maneiras de empreender laços sociais eram assimétricas. Os compadrescos e os elos sociais expressos em testamentos e nos casamentos demonstram que as relações variavam conforme o lugar na hierarquia. Em geral, os Rochas tinham como padrinhos de seus filhos donas, tenentes, capitães e reverendos, mas apadrinhavam e testemunhavam casamentos de escravos, filhos de pessoas sem títulos, de forros, etc. O problema é que certos forros Rochas não teceram vínculos com seus escravos e agregados, não se empenharam. Como dizia Antônio Manuel de Almeida: "Era no tempo do Rei (...) Já naquele tempo (...) o empenho, o compadresco, eram uma mola real de todo o movimento social". ${ }^{68}$ Mas não apenas no tempo do Rei; do Imperador, também.

\section{Legados Materiais}

Em 1820, o monte-mor do padre era de $776 \$ 474$ réis brutos e a única dívida passiva era de $51 \$ 202$ réis, devidos a Jesuíno. ${ }^{69}$ Cada herdeiro ficou com $121 \$ 115$ réis. Não era muito, mas o padre escreveu no testamento que fez doações em vida. Comparando, pelas listas nominativas, seus escravos de 1815 com os de Jesuíno de 1820, percebe-se que Jesuíno ficou com a

Rio de Janeiro: Civilização Brasileira, 2007, p.313-347; BRÜGGER, Silvia Maria Jardim. Minas patriarcal: família e sociedade (São João Del Rei - séculos XVIII-XIX). São Paulo: Annablume, 2007, cap.5.

68 ALMEIDA, Manoel Antônio de. Memória de um sargento de milícias. São Paulo: Ática, 1985, p.9, 126.

$69 \mathrm{MRCl}$. Pasta 237, doc.3. 
maior parte dos cativos produtivos, João Banguela, Joaquim Angola/Banguela, Marcos e Vicente. Jesuíno ainda desfrutava do trabalho de Antonia, casada com o escravo Vicente. Por fim, desfrutou do trabalho dos irmãos Abraão, Domingos e Samuel.

Os outros irmãos de Jesuíno não receberam o mesmo número de cativos. Generoso da Rocha não tinha escravos em seu domicílio, nem Benigno, agregado de seu sogro. Lucinda da Rocha possuía apenas um escravo em 1843, Esmelinda da Rocha, dois, e Celestina Maria da Rocha, apenas uma. Celestina empobreceu e, por isto, quando a matriarca fez seu testamento, em 1836, afirmou:

Eu, Maria Francisca da Rocha (...) fui casada com Francisco da Rocha, já falecido, de cujo falecido tive os filhos de nomes Jesuíno e Generoso, já falecidos, e Benigno, Celestrina, Lucinda, Esmelinda, os quais são meus legítimos herdeiros. Declaro ser minha última vontade deixar minha terça aos meus legítimos herdeiros Benigno e Celestina, o primeiro por muito me ter servido, e a segunda pela suma pobreza em que se acha; os mais de meus bens serão repartidos entre meus herdeiros. Por ser esta minha última vontade (...) [Ao] Senhor Antônio Vaz Almeida, que é tutor de meu neto Prudente, filho do falecido meu filho Generoso, (...) muito recomendo o bom arranjo de meu neto (...). Assino a rogo de Maria Francisca da Rocha, Francisco Antônio de Moraes Abreu. ${ }^{70}$

\section{As mortes de Maria Francisca, Jesuíno e Generoso José da Rocha}

Como Maria disse em testamento, Jesuíno e Generoso já eram falecidos. Na verdade, os anos de 1835 e 1836 foram decisivos para os descendentes, pois Jesuíno, Generoso e a matriarca morreram nestes anos. Jesuíno faleceu em 17 de janeiro de 1835. Generoso se foi em 25 de agosto de 1835. Não teve tempo de fazer testamento, pois morreu "repentinamente"..$^{71}$ Testar era uma ocasião para distribuir recursos entre os herdeiros através da terça, deixar legados, etc. ${ }^{72}$ Às vésperas da morte, Maria Francisca se preocupou com o neto e com a filha, deixando a esta metade da terça.

No processo de empobrecimento de Celestina e seu marido, o casal foi se desfazendo dos bens legados pelo padre. Ainda em julho de 1830, venderam uma sorte de terras a João Leite de Camargo, casado com Esmelinda, a irmã de Celestrina, isto é, o comprador era cunhado. É digno de nota que a condição da venda das terras era a de o comprador não repassá-las a "pessoas estranhas sem ser ofertada aos herdeiros do falecido padre André da Rocha Abreu, por ser assim feita por ele a doação, e bem

70 MRCI. Pasta 106, doc.1. Testamento de Maria Francisca da Rocha.

71 ACDS. Livro de Óbito de Brancos e Libertos (1834-1866), f. 5v. e 8v.

72 NAZZARI, Muriel. O desaparecimento do dote. Mulheres, família e mudança social em São Paulo, Brasil, 1600-1900. São Paulo: Companhia das Letras, 2001. 
assim poderem os vendedores conservar seus animais nos campos". ${ }^{73} \mathrm{~A}$ compra da terra a um parente pode visar uma ajuda aos vendedores, já que o cunhado comprador permitiu o uso da terra pelos parentes empobrecidos. Em sociedades pré-industriais, o mercado de terras é baseado em relações pessoais e parentais. ${ }^{74}$ Mais, para os forros Rochas, a solidariedade familiar, além de garantir as condições de sobrevivência, talvez almejasse preservar a distinção da família, ou livrá-la da pobreza.

Aliás, na escritura de doação do padre, fica evidente que sua intenção em doar as terras naquelas condições (não repassá-las a pessoas estranhas sem ser ofertada aos herdeiros) era manter os irmãos unidos após sua morte, para auxílio mútuo e para a não dispersão dos bens, mesmo que para isso beneficiasse um entre os herdeiros. Talvez resida aí o privilégio dado a Jesuíno. De qualquer modo, coube sobretudo a este forro senhor, e depois a sua esposa, perpetuar o status senhorial da família.

Segundo as palavras de Maria Francisca da Rocha, ela também se preocupou com o destino de outros herdeiros. Para o neto Prudente, escolheu um tutor. O "pardo" Prudente, batizado em dezembro de 1825, órfão aos dez anos, casou em 1844, então nomeado Prudente Marques Rocha. Foi pai de quatro filhos. ${ }^{75}$

Bengino também foi privilegiado com a terça de sua mãe, cujo argumento para lhe deixar o legado não foi de natureza econômica, mas de gratidão maternal. Divorciado e sem filhos, Benigno provavelmente cuidou de sua mãe e não era destituído de posses. Em 13 de maio de 1836, quando registrou as condições de seu divórcio, devia pagar à sua mulher o equivalente em dinheiro à metade do valor de uma casa, o que ele fez. Além da casa, tinha uma parte no engenho de seu irmão Jesuíno, como este disse em testamento. ${ }^{76}$

Sobre o destino material de Lucinda, pouco se sabe. Morreu em 17 de março de 1851, aos 50 anos de idade, sendo enterrada no cemitério e conduzida em caixão, o que não era para todos. ${ }^{77}$ Por sua vez, o marido de Esmelinda Rocha comprou as terras de sua irmã e o casal tinha uma olaria e dois escravos em 1836, o que Ihes rendia $120 \$ 000$ anuais. ${ }^{78} \mathrm{O}$ ramo de Esmelinda, processado em 1864, prosperou ou manteve-se como senhor.

Por fim, Jesuíno José da Rocha estava longe de precisar do amparo material de sua mãe. Recebeu os maiores legados do padre André, além

\footnotetext{
73 MRCI. Pasta 176, Livro 12, f. 53.

74 LEVI, Giovani. A herança imaterial; FRAGOSO, João Luís Ribeiro. A formação da economia colonial no Rio de Janeiro e de sua primeira elite senhorial. In: FRAGOSO, João Luís Ribeiro et alli. (orgs.) O Antigo Regime nos trópicos. A dinâmica imperial portuguesa. Rio de Janeiro: Civilização Brasileira, 2001, p.29-73.

75 ACDS. Casamentos de Livres, Livro 6 (1837-1851), f.29. Batismos de Livres, Livro 6 (1837-1851), f.26v, 53v, 84v e $143 \mathrm{v}$.

76 MRCI. Pasta 107, doc.24. Testamento de Jesuíno José da Rocha (pai).

77 ACDS. Óbitos (1834-1860), f.50v. Entre 1.557 óbitos de livres, para o período que vai de 1834 a 1860, em apenas $103(6,6 \%)$ os defuntos foram conduzidos em caixão.

78 LNPF. Ano de 1836, Q.8, f.17.
} 
de ser testamenteiro e inventariante. Em 1820, senhor de engenho, pardo, solteiro, produziu 100 arrobas de açúcar. Consigo residiam ex-escravos de André. Em 1824, este senhor de engenho pardo, de 33 anos de idade, produziu 350 arrobas de açúcar, com o trabalho de 17 escravos. Em 1829, aos 39 anos, senhoreava 22 escravos, dos quais 18 com mais de 14 anos. Ainda senhor de engenho pardo, produziu 400 arrobas de açúcar. Não mais havia agregados. ${ }^{79} \mathrm{Em}$ síntese, de subalterno se tornou proprietário de homens, herdando do padre André a condição senhorial.

Ao contrário de seus irmãos e cunhados, Jesuíno e sua esposa tiveram uma considerável ascensão social, distanciando-se mesmo de seus parentes. Em 1822, o filho do casal foi apadrinhado pelo reverendo Bento Paes de Campos, testemunha no testamento do padre André. Deu o outro filho, o homônimo, para ser batizado por um alferes. Quando Jesuíno testou, pediu ao coronel, brigadeiro e Conselheiro Provincial, Joaquim José de Moraes Abreu, para cobrar dívidas em São Paulo.

Jesuíno não testemunhou casamentos de escravos e tampouco apadrinhou filhos de forros e/ou pessoas sem título. Sua mulher, depois de viúva, teve afilhados nesta situação, mas que não eram escravos. As testemunhas de casamento dos escravos de Jesuíno Pai eram pessoas que estavam em sua órbita, como o irmão Generoso, o cunhado Joaquim Rodrigues Viana, seus próprios escravos ou os herdados do padre André, seus agregados. ${ }^{80}$ Destarte, a ascensão social de Jesuíno Pai o levou ao relativo afastamento de seus escravos, ao menos pelo batismo. Quem o fazia eram seus parentes, mas não ele próprio ou seus filhos e sua mulher. Parece que o filho homônimo também não se importava, como disse uma testemunha. Bastou sua mãe Feliciana morrer, em 1878, para, no mesmo ano, a cativa Firmina e seus filhos moverem uma ação de manutenção de liberdade.

Evidentemente, o distanciamento em relação a escravos e forros não implica, por derivação, uma ruptura total, um mundo à parte, em relação a escravos ou a pessoas com antepassado escravo. Por isto, o distanciar-se do cativeiro é diferente de deixar de acionar identidades de acordo com as fluidas situações sociais, ainda que se mantenham hierarquias. Por exemplo, o irmão de Jesuíno, Generoso, e foi sepultado sem sacramentos nos campos da Irmandade da Boa Morte, uma devoção de negros e pardos. O próprio Jesuíno foi enterrado nos campos da irmandade de São Benedito, também uma devoção de negros e pardos, conduzido "em caixão" e "sepultado solenemente". Ambos guardavam, portanto, identidade com negros e pardos. ${ }^{81}$ Mas não com o antepassado escravo. Provavelmente, a cor não importava ou não deveria importar, mas a escravidão, sim. A

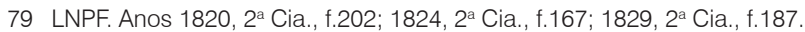

80 ACDS. Casamento de Escravos, Livro 2 (1787-1821), f. 83, 85v, 92v; Livro 3 (1821-1858), f.11v, f.46

81 ACDS. Óbitos de Brancos e Libertos, Livro s.n. (1834-1866), f.5v e 8v. 
respeito, Jesuíno Filho também pediu para ser enterrado nos campos de São Benedito, mas, a crer na testemunha, não se importava com os escravos, talvez nem com os que dependentes de sua família. Lembremos que uma das testemunhas ouviu do próprio João Rodrigues Viana que Jesuíno José da Rocha Filho, "expelindo-o da sua morada, iria tomar posse de sua concubina e filhos". Se foi o caso, Jesuíno Filho não ligou sequer para seu irmão de criação, um agregado subalterno que vivia em suas terras, e muito menos para seus escravos. A propriedade escrava, apenas, não justifica o exercício do poder e a legitimidade da escravidão. O cativeiro tinha que ter uma base moral, que podia ser por laços familiares ou de proximidade com os escravos ${ }^{82}$ ou por respeito aos laços parentais cativos. Os ramos dos Rochas processados parece que não o fizeram, ao menos Jesuíno Filho, processado em 1878.

\section{A doação da condição senhorial de André para Jesuíno (o pai)}

Desde 1813, Jesuíno era descrito no domicílio do padre André como organista, o que significa que o padre ensinou a arte da música para o forro. Esta herança o diferenciou de seus irmãos pelo resto da vida. Mas tão importante foi o número de escravos e os fatores de produção que o padre Ihe deixou. Depois da morte de Andre, Jesuíno passou a ser reconhecido como senhor de engenho. Em 22 de dezembro de 1834, o forro asseverou em seu testamento:

Declaro que sou natural desta vila, filho natural de Maria Francisca da Rocha, a qual ainda vive. Declaro que sou casado com Feliciana Maria de Jesus, de cujo matrimônio tenho dois filhos, José e Jesuíno, os quais são meus legítimos herdeiros. Declaro que deixo o meu piano com a condição de nunca poder vender, nem alienar e nem dar para dívida, e nem por maneira alguma poderá dispor; só sim concedo que um poderá vender para o outro, mas isto só o poderão fazer quando tenham de se apartar, saindo da casa em companhia de sua mãe depois de serem homens, por causa de casar-se ou a negócios, ou outro qualquer motivo semelhante (...) concedo que um irmão venda ao outro, cujas partes serão iguais a cada um; e igualmente deixo aos dois meus filhos meu órgão em igual parte a cada um com as mesmas condições, exatamente com que Ihes deixo o piano. Declaro que Luis Antônio da Silva Freire, da cidade de São Paulo, deve-me [69390], cuja clareza e obrigação se acham em poder do Coronel Joaquim José de Moraes Abreu, morador em a dita cidade, a qual the entreguei para ele cobrar, porém se advertindo que esta quantia não pertence só a mim, e sim pertence a mim e a todos os meus irmãos em igual parte. Declaro que se dará a meus irmãos e irmãs [68\$000] a cada um, entendendo-se que é a todos que são vivos até hoje, e se algum morrer primeiro que eu dar-se-á a dita

82 Silvia Brügger salientou que, não obstante comumente senhores não apadrinhassem cativos, seus parentes em geral o faziam. BRÜGGER, Silvia Maria Jardim. Escolhas de padrinhos, p.313-347; BRÜGGER, Silvia Maria Jardim. Minas patriarcal, cap.5. 
quantia a seus herdeiros legítimos, se os houver, e igualmente se dará à minha mãe [136\$000], e que tudo será satisfeito pela mesma terça. Declaro que meus irmãos Generoso e Benigno têm parte no meu sítio e engenho, conforme consta de escritura, aliás, de uma escritura de doação que tenho em meus papéis, que por ela se verá a parte que os mesmos têm, não entrando na parte deles uma caldeira que eu comprei e um alambique e moinho e mais obras que mandei fazer depois da morte do doador da sobredita escritura, e os mais que tenham partes por documentos se verá de que a não têm mais. ${ }^{83}$

Suas palavras demonstram que Jesuíno reconstruiu a condição de proprietário, investindo no engenho, reparando-o e comprando importantes fatores produtivos (uma caldeira, um alambique e um moinho), além de sua escravaria ter sido ampliada. A condição senhorial herdada por Jesuíno o tornou o centro distribuidor de recursos em sua família. Não recebeu nada de sua mãe porque não precisava, mas deixou legados a ela, que passou a outros herdeiros. Jesuíno também amparou os irmãos com legados, sem esquecer seus sobrinhos. Era distinto de seus irmãos no que tange ao grau de mobilidade social, mas se preocupou com o futuro de seus parentes, com a posição da família. Mais ainda, o sítio e o engenho dos Rochas pertenciam a membros da família. Portanto, trata-se de uma propriedade conjunta para propiciar a condição de senhor de engenho da família encabeçada por Jesuíno.

Enfim, e por peça do destino, o piano, símbolo de distinção social, levado para São Paulo em braço escravo, pertenceu a um homem nascido em cativeiro, filho natural. ${ }^{84}$ Parece que considerava o piano a maior herança do padre, a herança imaterial, tentando perpetuá-la em seus descendentes. Com ela a condição senhorial.

Em termos materiais, em 1836, o monte-mor de Jesuíno Pai era de 7:997\$008, e as passivas, de 1:862\$734 (23,3\%). ${ }^{85} \mathrm{~A}$ maior parcela da dívida era relativa à compra de escravos no Rio de Janeiro, então a fonte maior de braços escravos para o crescimento da população escrava na vila de Porto Feliz. Além de ter crédito externo e de se reafirmar como senhor, Jesuíno era muito bem relacionado com as elites locais. Os outros credores eram o tenente Manoel Fernandes Teixeira, o seu compadre alferes Domingos José de Faria, o capitão José Manoel Arruda, compadre de suas irmãs, o tenente Francisco de Oliveira Setúbal, também compadre de sua irmã. Preservou o laço com o "coronel Joaquim José de Moraes Abreu", filho do capitão que testemunhou o casório de seus pais.

Jesuíno deixara de ser escravo há muito tempo. Membro da elite local, morreu senhor de mais de 20 escravos. Ostentava um relógio de algibeira

$83 \mathrm{MRCl}$. Pasta 107, doc.24. Testamento de Jesuíno José da Rocha (o pai).

84 Jesuíno nasceu antes do casamento dos pais. Em 1798, tinha seis anos de idade e seus pais se casaram em 1794. Jesuíno José da Rocha não disse ao testar que era filho de Francisco da Rocha. Seria filho do padre André?

$85 \mathrm{MRCl}$. Pasta 247, doc.2. Inventário de Jesuíno José da Rocha. 
de ouro, botões de ouro de punho, etc. Era respeitado, pois um sargentomor da guarda nacional e negociante ${ }^{86}$ se obrigaria "por sua pessoa e bens" como "fiador e principal pagador na falta da pessoa e bens da viúva inventariante", dona Feliciana Maria de Jesus. Mas não precisou, já que a viúva soube governar seus bens, sua família e seus escravos. Acertou as contas com seus cunhados, relativas a legados de Jesuíno. Ainda em setembro de 1836, cerca de um ano e meio após o falecimento do marido, Feliciana constituiu um procurador em São Paulo para cobrar da Tesouraria provincial dívidas de aluguéis de casas. ${ }^{87}$

No mesmo ano, ela ainda tinha de 25 anos de idade e era mãe dos menores José e Jesuíno Filho, de sete e quatro anos, respectivamente. Tinham um sítio que rendeu 300 mil réis e 400 arrobas de açúcar. Em 1843, aos 32 anos, ela vivia de suas lavouras e os filhos José e Jesuíno estavam ao lado de mais dois irmãos, Augusto e Inocência. O sítio de novo rendeu 300 mil réis, produzindo 400 arrobas de açúcar. Havia uma agregada, negra, de 44 anos. ${ }^{88}$ Provavelmente, dona Feliciana se uniu a alguém, embora ainda fosse considerada viúva.

No tratamento com os escravos, casou seis deles após a morte do marido. Sua escravaria era basicamente africana. Dos três casamentos, em dois a mulher era viúva, com idades relativamente avançadas para gerar filhos. Perto das datas de seus casamentos, as cativas Teodora e Mariana tinham cerca de 40 anos. Não as vendeu e, dos cinco escravos presentes no domicílio em 1836, e ausentes em 1843, quatro eram adultos solteiros e uma era casada. Essa cativa casada chamava-se Fabiana. Suas núpcias com o escravo Paulo se deram em 1840. ${ }^{89}$ Ausentes do domicilio de dona Feliciana Maria de Jesus, deviam estar mortos ou alforriados em 1843. Fabiana é a mãe da cativa Firmina, que processou Jesuino Filho em 1878. Como os casamentos dos escravos da época de Dona Feliciana se deram todos após a morte de Jesuíno Pai, a Dona devia saber que cativos aparentados tinham uma função política imprescindível, a manutenção da paz das senzalas. ${ }^{90}$ Por isto, os escravos dados ao credor não eram aparentados. De longa data, o governos dos escravos efetuado pelos Rochas, incluindo os senhores forros, se fazia, também, com base no parentesco escravo. Ora, lembrando dos dizeres de uma testemunha, foi justamente com essa "paz nas senzalas", via parentesco, o que Jesuíno Filho visou romper: "Jesuíno José da Rocha" Filho," expelindo-o da sua morada, tomará posse de sua concubina e filhos".

86 LNPF. Antônio Vaz de Almeida, 1836, Q.1, f.27; 1843, Q.2 da Vila, f.171.

$87 \mathrm{MRCl}$. Pasta 176, Livro 12, f.51.

88 LNPF. Anos de 1836, Q.10, f.24, Bairro Santo Antônio; 1843, f.114.

89 ACDS. Casamento de Escravos, Livro 3 (1821-1858), f.. 85v.

90 GÓES, José Roberto e FLORENTINO, Manolo. A paz das senzalas. 
Quando o inventário de Felciana foi aberto, em 1878, 52 anos após a morte do marido, o monte-mor era de 9:900\$000, e as passivas apenas de $324 \$ 317$ (3,3\%). Os 14 escravos eram 100\% dos bens, que foram partilhados igualmente entre os seis herdeiros. ${ }^{91}$

\section{Palavras Finais: a memória do poder senhorial e a memória da submissão escrava}

Mas antes, em 1850, o promotor dos Resíduos cobrou de dona Feliciana a prestação de contas do inventário e testamento de seu marido. Um juiz aprovou as contas em janeiro de 1853 e, em 1862, outro juiz disse que nada havia "a provar em revisão das contas desta testamentária, visto a sua antigüidade maior de 25 anos, que desobriga a testamenteira de oferecer prova mais regular". Portanto, não precisava de "prova mais regular" em 1862. O pai, Jesuíno José da Rocha, era neto de escravos e filho natural de mãe escrava. Ao se tornar senhor, perpetuou em seus filhos as heranças imateriais do seu antigo senhor, conduzidas, literalmente, pelo braço escravo, seja o piano, seja o nome senhorial, seja o engenho. Jesuíno José da Rocha construiu um filho homônimo e um com sobrenome Rocha Abreu, o mesmo sobrenome do padre. Batizara seu primeiro filho com o nome do padre. Era a condição senhorial estendendo-se no tempo, reproduzindo a desigualdade, e nomeando-a. Sua mulher preservou os escravos.

Um dos filhos do casal, José da Rocha Abreu, casou-se e teve dois filhos. O primeiro se chamava André, em homenagem ao padre que ele sequer conheceu, mas que a família guardava vivo na memória. O outro rebento tinha o nome de Maria, uma homenagem à avó ou à mãe. José da Rocha Abreu morreu em 1876 e estava com o piano e uma casa térrea perto da Igreja. Seus bens somavam 1:352\$102, sem escravos, e com um passivo de apenas $83 \$ 930 .{ }^{92}$

Jesuíno José da Rocha, o filho homônimo, casou e foi pai de cinco filhos, todos com sobrenome Rocha, exceto Feliciana Maria de Jesus, uma homenagem à sua mãe. Como seus tios, também tinha filhos denominados Augusto e Leopoldina, preservando a memória parental. Quando sua mãe morreu, Jesuíno Filho continuou senhor de escravos, que constituíam todos os bens maternos. Mas duas testemunhas favoráveis aos escravos disseram que dona Feliciana "vivia pobremente, apesar de ter escravos", acrescentando que "Vianna sustentava" Firmina e seus filhos "pelo facto de viverem em sua companhia, como se fossem sua mulher e filhos". O advogado do réu e suas testemunhas rebateram e afirmaram que "as autoras prestam

91 Feliciana foi mãe de mais quatro filhos. MRCI. Pasta 312, doc.2. Inventário de Feliciana Maria de Jesus. $92 \mathrm{MRCl}$. Pasta 310, doc.3. Inventário de José da Rocha Abreu. 
obediência e serviços ao réu na qualidade de escravos porque moram em terras dele e ele é quem estava à testa dos escravos de sua finada mãe".

$\mathrm{O}$ advogado de Jesuíno utilizou o argumento de Firmina e seus filhos menores, Josefina e Cândido, que, segundo ele, diziam

que vivendo eles, há anos, em companhia de José Rodrigues Viana, com economia própria, sem outra sujeição que a natural, Jesuíno Jose da Rocha, filho e inventariante de dona Feliciana Maria de Jesus, julgando-se com direito sobre os Suppes, os submeteu a seu poder e os privou assim da liberdade.

A alusão à "dona" Feliciana não é desprovida de sentido. Jesuíno provinha de uma família abastada e ao mesmo tempo oriunda do cativeiro. Seus avós e tios foram senhores. Seus ascendentes, tios e primos se aparentavam espiritualmente a membros da elite local. Jesuíno Filho integrava o ramo da família forra Rocha que mais prosperou, desde que seu pai homônimo, organista da vila, se tornara senhor de engenho quando da morte do padre, em 1820. Mas a morte cedo levou seu pai, precisamente em 1836. A partir de então os cativos se concentraram nas mãos de Feliciana Maria de Jesus, sempre reconhecida como "dona", que tinha 14 escravos em 1878, quando morreu. Então, a cativa Firmina abriu o processo de manutenção de liberdade, posto que ela e seus filhos foram "apresentados como escravos no inventário de Feliciana Maria de Jesus".

O casal Jesuíno pai e dona Feliciana aprendeu grande parte do governo dos escravos com o padre André. Construíram sua escravaria quando o tráfico atlântico de cativos alimentava a vila de homens e mulheres africanos. O vigário tinha certas regras de prioridade para alforriar seus cativos. Em geral, deixava os homens no cativeiro e libertava suas esposas. Depois da morte do padre, não foi outra a prática do casal Jesuíno pai e "dona" Feliciana, com a diferença de que os alforriados eram os homens, ao passo que as mulheres permaneciam no cativeiro. ${ }^{93}$ Nessa prática senhorial, ser um cativo casado não era suficiente para ganhar a alforria, mas sem o ser não se chegava a ela. Foi este o ensinamento que o casal recebeu do padre. "dona" Feliciana assim procedeu depois de viúva.

Retornemos agora a Jesuíno Filho, que deve ter visto o procedimento de seus pais, sobretudo o de sua mãe, em especial o modo como conduziram o governo dos escravos, a escravização e a libertação. Para quase todo o Oitocentos, em mais de 300 processos de natureza variada não localizamos, salvo o contra Esmelinda Rocha e seu marido João Leite de

93 As práticas alforria de André da Rocha Abreu, Jesuíno José da Rocha e Feliciana Maria de Jesus podem ser percebidas pelas listas nominativas, pelos testamentos, inventários e pelas alforrias em cartório. A referência para a alforria em cartório é MRCI. Pasta 176, Livro 12, f.41. 
Camargo, nenhum caso de contestação da escravidão na parentela de Jesuíno José da Rocha. ${ }^{94}$

Além de não se importar e não se aparentar com escravos e forros, Jesuíno Filho vivenciou um momento peculiar da escravidão ao qual nos referimos, isto é, aquele de pressões sociais e institucionais que incidiram sobre a escravidão, inclusive a demográfica. Jesuíno tinha um irmão, falecido em 1876, mas era ele quem concentrava os escravos herdados de sua mãe, reafirmando a condição senhorial da família. Não apenas a propriedade escrava, mas o nome senhorial; prática de perpetuação que a família fez questão de reatualizar ao longo de gerações. O processo movido pela escrava Firmina, muito além de mexer com as prerrogativas de escravizar e libertar, tocava fundo no status senhorial quase secular da família. Assim, com tudo isso, Jesuíno demonstrou que ao arrefecimento da escravidão não correspondeu o refluxo das atitudes senhoriais e dos valores escravistas da família. Lutou até onde pôde para preservar seu nome senhorial. Com certeza, o lugar da família estava gravado em sua memória.

A cativa Firmina e seus filhos ganharam a causa e Jesuíno Filho pagou as custas. Mas como o resultado de um processo por si só não leva à compreensão dos valores sociais de uma determinada sociedade, cabe continuar a destacar que argumentos a comunidade utilizou para justificar a escravidão e a liberdade. O advogado do senhor e réu dizia que "se os autores pedem em juízo mandado de manutenção, têm necessidade de demonstrar que estavam na posse de sua liberdade" e que a perderam por um ato qualquer e que só pode consistir em uma violência. Mostra-se que no ano de 1836, a crioula Fabiana fora avaliada no inventário de Jesuíno Pai, quando tinha 12 anos. Que de Fabiana nasceu Firmina, e que desta nasceram Josefina e Cândido. Ou seja, a família estava, pelo menos, há 3 gerações no cativeiro. Prosseguia o advogado de Jesuíno e argumentava que Firmina e seus filhos, longe de serem considerados libertos, sempre estiveram sob o poder dominical, tanto que foram matriculados como escravos em tempo útil e foram sujeitos à taxa de escravos. Depois da morte de sua senhora, Firmina agenciou donativos para sua liberdade, e só usou do procedimento judicial depois da ineficácia desse meio, o que demonstra reconhecimento do seu estado de escravidão. Por fim, dizia que Viana, amásio de Firmina, foi criado e educado em casa da mãe do réu, e ainda era agregado e morador em terras do Réu, a quem, como representante de sua mãe, as autoras eram sujeitas prestando-lhe obediência e serviços em sua qualidade de escravas. O advogado e o réu pensavam que a au-

94 Há um auto de liberdade movido por Firmina contra os herdeiros de Dona Feliciana Maria de Jesus, mas trata-se da continuidade do processo anterior, ambos de 1878. Requer-se que os herdeiros de assinem termo de desistência do poder e domínio sobre Firmina e seus filhos. MRCl. Pasta 12, doc.19. Os autos de liberdade totalizam 27. 
toridade senhorial da mãe se prolongaria no filho. Evocavam a prestação de serviços e o domínio senhorial como provas de escravidão.

Mas as cativas crioulas, cuja família estava há três gerações no cativeiro, julgavam que após a morte de sua ex-senhora seriam libertas. Deviam saber que crioulos tinham mais chances de chegar à alforria na vila, ${ }^{95} \mathrm{O}$ que, somado às pressões em prol da liberdade, as ajudariam a chegar à nova condição jurídica. Firmina fora batizada em 1840, estando com cerca de 38 anos à época do processo. Na matrícula datada de 8 de agosto de 1872, fora descrita como uma mulata de 30 anos, solteira, do serviço de roça, morando "fora da cidade". Seus filhos, Josefina, 5 anos de idade, e Cândido, 1 ano, eram mulatos. Como a Lei do Ventre Livre data de 28 de setembro de 1871, a legislação não favorecia Cândido, já que o pequeno cativo nasceu meses antes da lei. ${ }^{96} \mathrm{Na}$ matrícula de 1874, a família estava na mesma situação de cativeiro. Carregando 54 anos de escravidão familiar, parece que a família, de pai livre, acreditando na mobilidade social geracional, ${ }^{97}$ não teria outro recurso para tirar todos os seus membros do cativeiro senão mover um processo. Tentaram em vão agenciar donativos para sua liberdade. Excluídos da lei de 1871, restava apenas a auto-compra, mas não conseguiram recursos, sequer moravam em terras próprias. Ainda assim, o curador e suas testemunhas insistentemente diziam que viviam apartados da casa de sua antiga senhora "pobre, apesar de ter [14] escravos". Afirmavam também que erm autonônomos em seu sustento. Viana era um verdadeiro pai de família: "vivendo eles, há anos, em companhia de José Rodrigues Viana, com economia própria". Todavia, pairava o risco de mais uma geração viver no cativeiro. Lembremos de Rosa de Arruda, cujo dever de madrinha a impulsionou a libertar seu afilhado do cativeiro dos Rochas. A memória do cativeiro e de submissão familiar pesava sobre essas cabeças?! Firmina não era casada, mas vivia como tal. Queria a alforria. Era assim que dona Feliciana procedia.

Por sua vez, por volta dos seus 42 anos de idade, o órfão de pai Jesuíno Filho, cujo irmão morrera 2 anos antes do processo, agora, em 1878, se via também órfão de mãe. Seus tios forros senhores já se tinham ido para o

95 Abordamos o tópico em GUEDES, Roberto. A Amizade e a alforria: um trânsito entre a escravidão e a liberdade (Porto Feliz, SP, século XIX). Revista Afro-Ásia, Salvador, v.35, p.83-141, 2007.

96 ACDS. Batizado em 21 de Fevereiro de 1871, Livro 9 (1863-1872), f.131.

97 Óbvio que o movimento nem sempre é linear, como prova o próprio caso de Firmina, ameaçada de voltar ao cativeiro. Para uma poderação da idéia de moblidade geracional familiar em direção à liberdade, cf. MACHADO, Cacilda. A trama das vontades. Aliás, para José Góes um "tipo de família que devia ser muito comum no Brasil daquela época [1863]" era "uma família que reunia membros escravos, livres e libertos. Talvez a típica família brasileira (...) tenha sido a que tinha um pé na liberdade e outro no cativeiro". GÓES, José Roberto. Padrões de alforria no Rio de Janeiro, 1840-1871; SAMPAIO, Antônio Carlos Jucá et alli. (orgs.) Nas rotas do Império, v.1, p.517-568. A mesma assertiva se vê em Sandra Grahan, ao afirmar que não "há motivos para supor que essa família [mista juridicamente] era excepcional: com certeza havia outras que atravessavam os limites legais entre as condições de escravo, pessoa livre e liberto". GRAHAM, Sandra Lauderlale. Caetana diz não: histórias de mulheres da sociedade escravista brasileira. São Paulo: Companhia das Letras, 2005, p.59. As misturas jurídicas, ou as "famílias mistas", entretanto, não as impediam de tentar tirar seus membros do cativeiro. 
além-túmulo. Somente a ele cabia perpetuar a escravidão e o nome senhorial da família. Mais do que escravidão ou liberdade por si sós, tratava-se da manutenção do lugar da família no topo da hierarquia escravista, onde sempre esteve. Sendo assim, as ações de manutenção de liberdade punham em xeque, não apenas as prerrogativas senhoriais, mas o status senhorial da família, secularmente construído.

O juiz deu ganho de causa a Firmina e seus dois filhos. Teria o resultado servido de exemplo para os demais escravos herdados por Jesuíno? Lembremos que os cativos herdados eram 100\% dos bens de sua mãe. Não há outros processos contra os Rochas, o que indica que não, mas não há certeza. De qualquer modo, quase quatro anos após a proclamação República, Jesuíno não era mais senhor de escravos. Então, deixou no testamento o único vestígio de antepassado escravo e de suas derradeiras vontades de família senhorial. Como de praxe, disse o nome dos pais, de sua mulher e de seus filhos. Queria ser "enterrado no Cemitério de São Benedito desta cidade", lugar onde estava seu pai. Faltava um mês e 12 dias para o Natal de $1893 .{ }^{98}$

\section{Anexo 1}

As referências documentais para os laços de compadresco dos filhos dos Rochas forros são: (A) Batismos dos filhos do casal Joaquim de Toledo e Lucinda Maria Rocha. ACDS. Batismos de Livres, Livro 1-B (1819-1825), fl. 83 v; Livro 2-A (1818-1829), fl. 4 e 35; Livro 5 (1834-1846), fl 22 v e fl. 83. Domicílios do Casal: LNPF.Ano 1836, Q. 4, f. 47; 1843, Q. 1, f. 9. (B) Batismos dos filhos do casal João Leite Camargo e Esmelinda Maria Rocha. ACDS. Livro 5 (1834-1846), fl. 19 v, 60 v, 79, 118 v, 161 v, 186; Livro 6 (1846-1860), fl. 14 e 70. Domicílios do Casal: LNPF.Ano 1836, Q. 8, f. 36. (C) Batismos dos filhos do casal Joaquim Rodrigues Viana e Celestina Maria Rocha. ACDS. Livro 1-B (1819-1825), fl. 50v, 78; Livro 2-A (1825-1829), fl. 27v, 59; Livro 5 (1834-1846), fl. 21, 40 e 85. Domicílios do Casal: LNPF.Ano 1824, $1^{\text {a }}$ cia, f. 7; 1829, $2^{\text {a }}$ cia, f. 4; 1836, Q. 1, f. 26; 1843, Q. 1, f. 5. (D) Batismos dos filhos do casal Jesuíno José Rocha e Feliciana Maria de Jesus. ACDS. Livro 1-A (1807-1819), fl. 64 v; Livro 1-B (1819-1825), fl. 10 v, fl. 62 v.

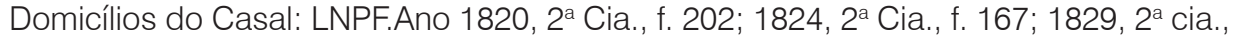
f. 187. (E) Batismos dos filhos de Generoso José Rocha, ACDS. Livro 2-A (1825-1829), fl. 16 e 69 v. Casamento de Generoso José Rocha e Maria Rodrigues Prudência: ACDS. Casamento de Livres, Livro 4 (1818-1837), fl. 81 v. Domicílio do Casal, LNPF.Ano 1829,

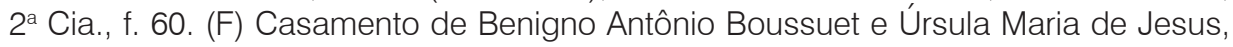
ACDS. Casamento de Livres, Livro 4 (1818-1837), fl. 53 v. Sem filhos. (G) Batismos dos filhos do casal Prudente Marques Rocha e Dulcelina Maria Toledo, ACDS. Livro 6 (18461860), fl. 26v, 53 v, 84v, 143 v. Casamento de Prudente e Dulcelina, ACDS. Casamento de Livres, Livro 6 (1837-1851), fl. 29.

$98 \mathrm{MRCl}$. Pasta 326, doc.16. Inventário de Jesuíno José da Rocha Filho. O testamento está anexo ao inventário. 


\section{Anexo 2}

As referências documentais sobre os compadres dos Rochas forros são: (A) Antônio Marques Piedade, MRCI. Pasta 243, doc.1; (B) Casal Salvador Arruda Penteado e Maria Diniz Ferraz: ACDS. Casamento de Livres, Livro 6 (1837-1851), f.16v. Pais do Noivo: Leonardo Arruda Penteado e Maria Arruda Sá, LNPF.1808, $1^{\text {a }}$ Cia, f.51; 1810, $1^{\text {a }}$ Cia, f.42; 1820, $2^{a}$ Cia, f.183; 1829, 2 Cia., f.198; 1836, Q.10, f.25. (C) Casal Luis Paes Almeida e Balbina Paes Arruda: ACDS. Casamento de Livres, Livro 6 (1837-1851), f.40v. Informação sobre patente do pai do noivo, Antônio Paes Almeida, casado com Gertrudes Maria Matos: LNPF. Anos 1798, $2^{\mathrm{a}}$ Cia., f.3; 1803, $2^{\mathrm{a}}$ Cia., f.3; 1805, $2^{\mathrm{a}}$ Cia., f.3; 1808, $2^{\mathrm{a}}$ Cia., f.3; 1810, 2a Cia., f.3; 1813, $2^{\text {a }}$ Cia., f.2; 1815, $2^{\text {a }}$ Cia., f.3; 1818, $4^{\text {a }}$ Cia., f.3; 1820, 4ª Cia., f.3; 1824, 4ª Cia., f.6; 1829, 2a Cia., f.209; 1836, Q.10, f.18. A informação sobre a patente do pai da noiva consta do registro de casamento. (D) Casal José Toledo Pizza e Ana Francisca Moraes: LNPF. Ano, 1805, 2 ${ }^{\mathrm{a}}$ Cia., f.223; 1808, $2^{\mathrm{a}}$ Cia., f.255; 1813, $2^{\mathrm{a}}$

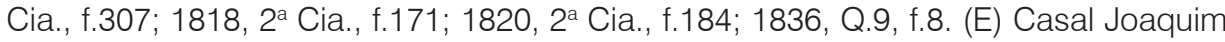
Toledo Pizza e Isabel Arruda Campos: LNPF. Ano, 1843, Q.10, f.582. (F) Casal José Manoel Arruda e Ana Manoela Moraes: LNPF. Ano, 1815, $2^{\mathrm{a}}$ Cia., f.114; 1820, $2^{\mathrm{a}}$ Cia., f.8; 1824, $2^{a}$ Cia., f.5; 1829, 4 Cia., f.109; 1843, Q.11, f.600. (G) Casal Francisco Correa Toledo e Ana Esméria Arruda: ACDS. Casamento de Livres, Livro 6 (1837-1851), f.5 v. (H) Casal Domingos José de Faria e Ana Maria Teixeira: LNPF. Ano 1818, 4ª Cia., f.112; 1820, $4^{\text {a }}$ Cia., f.123; 1824, $1^{\text {a }}$ Cia, f.9; 1829, $1^{\text {a }}$ Cia, f.9; 1836, Q.11, f.2; 1843, Q.5, f.367. (I) Casal Francisco Oliveira Setúbal e Isabel Arruda Leite: LNPF. Ano 1803, $2^{a}$ Cia., f.33;

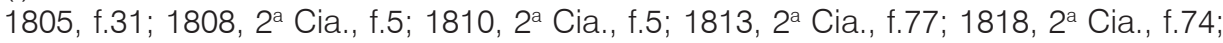

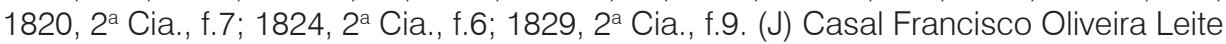
Setúbal e Ana Teresa Oliveira Campos: LNPF. Ano 1843, Q.3, f.187. ACDS. Casamento de Livres, Livro 4 (1818-1837), f.87v. (K) Padrinho Vicente Ferreira Campos: LNPF. Ano 1803, $2^{a}$ Cia., f.52; 1805, $2^{a}$ Cia., f.6; 1808, $2^{a}$ Cia., f.31; 1810, $2^{a}$ Cia., f.35. 1813, $2^{a}$ Cia.,

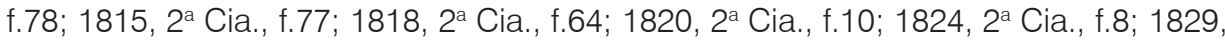
$2^{a}$ Cia., f.40; 1836, Q.1, f.7. (L) Padrinho Francisco Antônio Moraes Abreu/Leite: LNPF. Ano 1818, $1^{\text {a }}$ Cia., f.4; 1820, $1^{\text {a }}$ Cia., f.5; 1824, $1^{\text {a }}$ Cia., f.4; 1829, $1^{\text {a }}$ Cia., f.2; 1836, Q.1, f.3; 1843, Q.1, f.2. (M) Madrinha Gertrudes Correa Leite: LNPF. Ano 1824, $2^{a}$ Cia., f.15; 1829, $2^{a}$ cia., f.39; 1836, Q.2, f.131. A informação sobre o cônjuge consta do registro de batismo. (N) Madrinha Gertrudes Correa Leite: LNPF. Ano 1843, Q.4, f.291. 